\title{
Emerging Equity Markets and Economic Development
}

\author{
Geert Bekaert \\ Columbia University, New York, NY 10027 \\ National Bureau of Economic Research, Cambridge, MA 02138 \\ Campbell R. Harvey \\ Duke University, Durham, NC 27708 \\ National Bureau of Economic Research, Cambridge, MA 02138 \\ Christian Lundblad* \\ Board of Governors of the Federal Reserve System, Washington, DC 20551 \\ February 1, 2001
}

\begin{abstract}
We provide an analysis of real economic growth prospects in emerging markets after financial liberalizations. We identify the financial liberalization dates and examine the influence of liberalizations while controlling for a number of other macroeconomic and financial variables. Our work also introduces an econometric methodology that allows us to use extensive time-series as well as cross-sectional information for our tests. We find across a number of different specifications that financial liberalizations are associated with significant increases in real economic growth. The effect is larger for countries with high education levels.
\end{abstract}

JEL Classification: F3, G0, O1

* We have benefitted from the comments of Rodolfo Apreda, Sebastian Edwards, Miguel Ferreira, Peter Henry, the participants at the NBER Inter-American Seminar on Economics, December 2-4, 1999, in Buenos Aires, the 2000 European Finance Association Meetings in London, the American Finance Association Meetings in New Orleans and the suggestions of an anonymous referee. The views expressed are those of the authors, and do not necessarily reflect the views of the Federal Reserve System. Send correspondence to: Campbell R. Harvey, Fuqua School of Business, Duke University, Durham, NC 27708. Phone: (919)-660-7768, E-mail: cam.harvey@duke.edu. An electronic version of the paper is downloadable at http://www.fuqua.duke.edu/ charvey/Research/Working_Papers/W49_Emerging_equity_markets.pdf. 


\section{Introduction}

We present new evidence on the relation between financial equity market liberalizations and economic growth for a collection of emerging economies. We find that average real economic growth increases between 1 and $2 \%$ per annum after a financial liberalization. Our results are robust across a number of different economic specifications. This analysis, of course, reveals no causality. However, even after we control for a comprehensive set of macroeconomic and financial variables, our financial liberalization indicator retains significance.

There is a substantial literature that tries to explain the cross-sectional determinants of economic growth. Barro (1991) and Barro and Sala-i-Martin (1995) explore the ability of a large number of macroeconomic and demographic variables to explain the cross-sectional characteristics of economic growth rates. More recent research in the growth literature has focused on the potential benefits of economic integration (the degree to which trade flows are free) and general financial development. For example, Rodrik (1999) examines the relation between openness to trade and economic growth with a standard cross-country regression methodology. With a proxy for the general openness to trade, the evidence suggests that the relation between economic growth and openness is statistically weak.

Following the development of endogenous growth models where financial intermediation plays an important role, there is also an interest in determining the influence of the financial sector on the cross-section of economic growth. King and Levine (1993) focus on several measures of banking development, and find that banking sector development is an important factor in explaining the cross-sectional characteristics of economic growth. Levine and Zervos (1998) explore the degree to which both stock market and banking sector development can explain the cross-section of economic growth rates. They find evidence in support of the claim that equity market liquidity is correlated with rates of economic growth. Additionally, they argue that banking and stock market development independently influence economic growth. They also find that there is little empirical evidence to support the claim that financial integration is positively correlated with economic growth.

Unlike previous work, we focus exclusively on the relation between real economic growth 
and financial liberalization. Our work is partially motivated by Bekaert and Harvey (2000) who examine the relation between financial liberalization and the dividend yield. While the dividend yield contains information about the cost of capital, it also houses information about growth prospects. A reduction in the cost of capital and/or an improvement in growth opportunities are the most obvious channels through which financial liberalization can increase economic growth. After finding reduced dividend yields for countries that undergo financial liberalization, Bekaert and Harvey also examine the relationship between economic growth and liberalization at very short horizons and find a positive association.

Our work is also distinguished by the extensive use of time-series as well as cross-sectional information. Indeed, the advent of financial liberalization suggests a temporal dimension to the growth debate that is not captured by the standard cross-country estimation methodology. Typically, the growth literature focuses on either a purely cross sectional analysis or a time-series dimension that is limited to at most three time-series observations per country. ${ }^{1}$ We employ a time-series cross-sectional estimation methodology using Hansen's (1982) generalized method of moments (GMM). Our estimation strategy is considerably different from the existing literature in that we exploit the information in overlapping time-series data. Given the novelty of this approach, the econometric methodology is discussed extensively. Furthermore, we conduct several Monte Carlo experiments to assess the properties of our estimation strategy in this economic environment. Levine and Renelt (1993) discuss the caution one must exercise when interpreting cross-country regressions. They demonstrate that the estimated coefficients are extremely sensitive to the conditioning variables employed. For this reason, we also consider a variety of different specifications.

The paper is organized as follows. Section 2 introduces the variables we employ in our empirical work. Section 3 explains the econometric methodology, and discusses the results of a Monte Carlo analysis. Section 4 details the empirical results, and Section 5 concludes.

\footnotetext{
${ }^{1}$ Some exceptions include Islam (1995) and Harrison (1996).
} 


\section{Financial Liberalization and Economic Growth}

Our empirical design is to explore the relation between real per capita GDP growth over various horizons and an indicator of official financial liberalization. The data are at the annual frequency from 1980 through 1997. We provide the official liberalization dates in the data appendix. These financial liberalization dates mainly represent the dates at which the local equity market was opened up to foreign investors. A detailed analysis of these dates and alternative sets of dates is provided in Bekaert and Harvey (2000). ${ }^{2}$

The set of variables that control for variation in economic growth rates across countries not accounted for by equity market liberalization fall into three categories: macroeconomic influences, banking development, and equity market development. More detailed information on the control variables, including data sources, are contained in data appendix.

The first set of variables are linked to the condition and stability of the macroeconomy: government consumption divided by GDP, the size of the trade sector divided by GDP, and the annual rate of inflation. We also include a human capital variable, secondary school enrollment. Barro and Sala-i-Martin (1995) argue that government consumption divided by GDP proxies for political corruption, nonproductive public expenditures, or taxation. Bekaert and Harvey $(1995,1997,2000)$ and Levine and Zervos (1998) employ the size of the trade sector as imports plus exports divided by GDP. This variable is employed as a measure of the openness of the particular economy to trade. Barro (1997) provides evidence suggesting a negative relationship between inflation and economic activity. Finally, Barro and Sala-iMartin (1995) demonstrate the positive relationship between education and economic growth.

Following the evidence presented in King and Levine (1993), we include a control variable for the relationship between development in the banking sector and economic growth. In this capacity, we employ private credit divided by gross domestic product. King and Levine (1993) argue that this measure of banking development isolates the credit issued by private banks, in contrast to that issued by a central bank. Furthermore, Levine and Zervos (1998)

\footnotetext{
${ }^{2} \mathrm{~A}$ chronology of important events related to financial market integration is available on the Internet in the country risk analysis section of http://www.duke.edu/ charvey.
} 
provide evidence that the effects the banking sector and stock market development have upon economic growth are separate, and they use this variable to capture the former.

The focus of this paper is on the relation between economic growth and equity market liberalization. We examine three variables to proxy for the more general development of the equity market: a measure of equity market size, the log of the number of domestic companies, and equity market turnover as a measure of market liquidity. Both Bekaert and Harvey (1997) and Levine and Zervos (1998) use the ratio of the equity market capitalization to gross domestic product as a measure of the size of the local equity market. Large markets relative to the size of the economy in which they reside potentially indicate market development. Bekaert and Harvey (2000) employ the log of the number of companies as a measure of market development. Atje and Jovanovic (1993) and Levine and Zervos (1998) provide evidence for a strong relationship between economic growth and stock market liquidity, and, therefore, we employ value traded divided by market capitalization in this capacity.

\subsection{Summary statistics}

Table 1 describes the sample of 30 countries that we employ in estimation, classified as either emerging or frontier by the International Finance Corporation (IFC), for which there are annual data extending from 1980 to 1997 . Table 2 presents the summary statistics for the macro economic variables. This includes average real per capita GDP growth rates across the 30 countries in our sample across two decades. For this variable, we provide means over the 1980's and 1990's, as well as for the full sample. The average growth rates differ substantially across time for many of the economies considered. Additionally, the rates of economic growth vary widely across the economies included. This paper focuses on the extent to which the time-series and cross-sectional differences can be explained by differing states of financial liberalization of the equity market.

Figure 1 presents evidence on the rates of economic growth both before and after the official liberalization date. Of the 21 economies that undergo financial liberalization in sample, 18 exhibit larger average GDP growth rates after the official liberalization dates. ${ }^{3}$ While this

\footnotetext{
${ }^{3}$ There are 24 countries that experience liberalizations in Table 1 . However, for three of the countries,
} 
evidence implies no causality, it motivates the exploration of the relationship between economic growth and equity market liberalization. Tables 2 and 3 present average values for the various macroeconomic and financial, respectively, control variables across these economies. As the average values of these control variables vary substantially in the cross-section, the problem in examining the economic growth rates across these economies before and after equity market liberalization is that the differences may be related to phenomena not related to the liberalization itself, but captured by the control variables. For example, in many countries macroeconomic reforms (including trade liberalization) happened simultaneously or preceded financial liberalization (see Henry (2000a)). Also, as Table 3 shows, the nineties displayed a marked increase in the size of stock markets of all countries. The number of domestic companies and turnover also increase for most countries. It is possible that these variables are correlated with our financial liberalization indicator. Consequently, we include in the regression specifications a set of variables, consistent with the existing growth literature, that control for variation in economic growth rates across economies and time potentially not accounted for by financial liberalizations.

\section{Methodology}

\subsection{Econometrics Framework}

The primary quantity of interest is the growth rate in the real per capita gross domestic product (GDP):

$$
y_{i, t+k, k}=\frac{1}{k} \sum_{j=1}^{k} y_{i, t+j} i=1, \ldots, N
$$

where $y_{i, t}=\ln \left(\frac{\mathrm{GDP}_{i, t}}{\mathrm{POP}_{i, t}} / \mathrm{GDP}_{i, t-1}\right), \mathrm{POP}$ is the population, and $N$ is the number of countries in our sample. Then, $y_{i, t+k, k}$ represents the annual, $k$-year compounded growth rate of real per capita GDP. In the growth literature, $k$ is often chosen to be as large as possible. Our framework differs significantly in that we use overlapping data, facilitating the employment Egypt, Israel and Morocco, the liberalization takes place in 1996 or 1997. Given our data sample ends in 1997, these three countries are omitted from Figure 1. 
of the time-dimension in addition to the cross-sectional.

Our regression specification is as follows:

$$
y_{i, t+k, k}=\beta^{\prime} \mathbf{x}_{\mathbf{i}, \mathbf{t}}+\epsilon_{i, t+k, k},
$$

for $i=1, \ldots, N$ and $t=1, \ldots, T$. Denote the independent (right-hand side) variables employed, as discussed in Section 2, as $\mathbf{x}_{i, t}$. While the error terms are serially correlated for $k>1, E\left[\begin{array}{ll}\epsilon_{i, t+k, k} & \mathbf{x}_{\mathbf{i}, \mathbf{t}}\end{array}\right]=\mathbf{0}$. The vector $\mathbf{x}_{i, t}$ includes the country-specific logged real per-capita GDP for 1980, which we call initial GDP hereafter. This variable is included to capture the "conditional convergence" discussed extensively in Barro (1997). To estimate the restricted system, consider the following stacked orthogonality conditions:

$$
g_{t+k}=\left[\begin{array}{rr}
\epsilon_{1, t+k, k} & \mathbf{x}_{1, t} \\
\vdots & \\
\epsilon_{N, t+k, k} & \mathbf{x}_{N, t}
\end{array}\right] \text {, }
$$

With $L$ the dimension of $\beta$, the system has $L \times N$ orthogonality conditions, but only $L$ parameters to estimate. This procedure differs from ordinary least squares, as $\beta$ is restricted to be identical across all countries, resulting in a system estimation that potentially corrects for heteroskedasticity across time, heteroskedasticity across countries, and correlation among country specific shocks (seemingly unrelated regression (SUR)).

Define $\mathbf{Z}_{\mathbf{t}}$, an $N \times(L N)$ matrix, as follows:

$$
\mathbf{Z}_{\mathbf{t}}=\left[\begin{array}{cccc}
\mathbf{x}_{1, t}^{\prime} & 0 & \cdots & 0 \\
0 & \mathbf{x}_{2, t}^{\prime} & \cdots & 0 \\
\vdots & & & \\
0 & 0 & \cdots & \mathbf{x}_{N, t}^{\prime}
\end{array}\right]
$$

Then, one can rewrite the $(L N) \times 1$ vector of orthogonality conditions in the following manner:

$$
g_{t+k}=\mathbf{Z}_{\mathbf{t}}^{\prime} \epsilon_{t+k}
$$


where

$$
\epsilon_{t+k}=\left[\begin{array}{c}
\epsilon_{1, t+k, k} \\
\vdots \\
\epsilon_{N, t+k, k}
\end{array}\right]
$$

To derive the GMM estimator, it is useful to express these quantities in matrix notation. Let

$$
\mathbf{X}_{\mathbf{i}}=\left[\mathbf{x}_{\mathbf{i}, \mathbf{t}}^{\prime}\right], \mathbf{Y}_{\mathbf{i}}=\left[y_{i, t+k, k}\right] \text {, and } \epsilon_{\mathbf{i}}=\left[\epsilon_{i, t+k, k}\right]
$$

Also,

$$
\mathbf{X}=\left[\begin{array}{c}
\mathbf{X}_{\mathbf{1}} \\
\vdots \\
\mathbf{X}_{\mathbf{N}}
\end{array}\right], \mathbf{Y}=\left[\begin{array}{c}
Y_{1} \\
\vdots \\
Y_{N}
\end{array}\right] \text {, and } \epsilon=\left[\begin{array}{c}
\epsilon_{1} \\
\vdots \\
\epsilon_{N}
\end{array}\right] \text {, }
$$

where $\mathbf{X}$ is a $T N \times L$ matrix and $\mathbf{Y}$ and $\epsilon$ are $T N \times 1$ matrices. Also, let

$$
\mathbf{Z}=\left[\begin{array}{cccc}
\mathbf{X}_{1} & 0 & \cdots & 0 \\
0 & \mathbf{X}_{2} & \cdots & 0 \\
\vdots & & & \\
0 & 0 & \cdots & \mathbf{X}_{N}
\end{array}\right]
$$

a $T N \times L N$ matrix. It follows,

$$
\epsilon=\mathbf{Y}-\mathbf{X} \beta
$$

Additionally,

$$
\begin{aligned}
\mathbf{g}_{T} & =\frac{1}{T} \sum_{t=1}^{T} g_{t+k} \\
& =\frac{1}{T}\left\{\mathbf{Z}^{\prime}(\mathbf{Y}-\mathbf{X} \beta)\right\}
\end{aligned}
$$

Employing this notation, the GMM estimator satisfies

$$
\hat{\beta}=\arg \min _{\beta}\left[\mathbf{g}_{T}^{\prime} \mathbf{S}_{T}^{-1} \mathbf{g}_{T}\right]
$$

where $\mathbf{S}_{T}$ is the inverse of the GMM weighting matrix (see below). The First Order Condition associated with this optimum is as follows:

$$
\frac{\partial \mathbf{g}_{T}^{\prime}}{\partial \beta} S_{T}^{-1} \mathbf{g}_{T}=0
$$


Note that

$$
\frac{\partial \mathbf{g}_{T}}{\partial \beta}=\frac{\mathbf{Z}^{\prime} \mathbf{X}}{T} .
$$

Hence, to set the first order condition to zero, we choose

$$
\hat{\beta}=\left[\left(\mathbf{X}^{\prime} \mathbf{Z}\right) \mathbf{S}_{T}^{-1}\left(\mathbf{Z}^{\prime} \mathbf{X}\right)\right]^{-1}\left[\left(\mathbf{X}^{\prime} \mathbf{Z}\right) \mathbf{S}_{T}^{-1}\left(\mathbf{Z}^{\prime} \mathbf{Y}\right)\right]
$$

This is a well-known result from IV-estimators in a GMM framework. We optimally choose the GMM weighting matrix to minimize the variance-covariance matrix of the estimated parameter vector; $\mathbf{S}_{T}$ is the estimated variance covariance matrix of $\left(\frac{1}{T} \sum_{t=1}^{T} g_{t}\right)$, taking all possible autocovariances into account:

$$
\mathbf{S}_{T}=\sum_{j=-\infty}^{\infty} E\left[g_{t+k} g_{t+k-j}^{\prime}\right]
$$

Using the identity matrix as the weighting matrix, first step parameter estimates are obtained as follows:

$$
\hat{\beta}_{1}=\left[\left(\mathbf{X}^{\prime} \mathbf{Z}\right)\left(\mathbf{Z}^{\prime} \mathbf{X}\right)\right]^{-1}\left[\left(\mathbf{X}^{\prime} \mathbf{Z}\right)\left(\mathbf{Z}^{\prime} \mathbf{Y}\right)\right] .
$$

Then, construct the first step residuals as follows:

$$
\hat{\epsilon}=\mathbf{Y}-\mathbf{X} \hat{\beta}_{1}
$$

For the second step estimation, we use $\hat{\epsilon}$ to construct the optimal weighting matrix $\hat{\mathbf{S}}_{T}^{-1}$. In the case of overlapping data $(k>1)$, the residuals follow an $\mathrm{MA}(k-1)$ process. This structure allows the consideration of four different specifications for the weighting matrix that facilitate increasingly restricted variance-covariance structures across the residuals in (2).

- Weighting Matrix I:

The most general specification facilitates temporal heteroskedasticity, cross-sectional heteroskedasticity, and SUR effects.

$$
\hat{\mathbf{S}}_{T}=\frac{1}{T} \sum_{t} \mathbf{Z}_{\mathbf{t}}{ }^{\prime} \epsilon_{t+k} \epsilon_{t+k}^{\prime} \mathbf{Z}_{\mathbf{t}}+\sum_{j=1}^{K}\left[1-\frac{j}{K+1}\right]\left(\sum_{t=j+1}^{T}\left(\mathbf{Z}_{\mathbf{t}-\mathbf{j}}{ }^{\prime} \epsilon_{t+k-j} \epsilon_{t+k}^{\prime} \mathbf{Z}_{\mathbf{t}}+\mathbf{Z}_{\mathbf{t}}{ }^{\prime} \epsilon_{t+k} \epsilon_{t+k-j}^{\prime} \mathbf{Z}_{\mathbf{t}-\mathbf{j}}\right)\right) .
$$


In order to ensure that the variance-covariance matrix is positive-definite, the NeweyWest (1987) estimator is employed. $K(>k)$ is chosen to be 9 which is large enough to sufficiently capture the longer lagged effects and to ensure consistency. As the time dimension in our sample, $T$, is small, we do not consider this weighting matrix specification in practice. In the interest of parsimony, we consider three restricted variance-covariance structures.

- Weighting Matrix II:

This specification facilitates cross-sectional heteroskedasticity and SUR effects, but not temporal heteroskedasticity. Define the $N \times N$ matrix $\hat{-}_{j}$ as follows:

$$
\hat{-}_{j}=\frac{1}{T} \sum_{t=j+1}^{T}\left(\epsilon_{t+k} \epsilon_{t+k-j}^{\prime}\right) .
$$

Then, the restricted variance-covariance matrix can be written as follows:

$$
\hat{\mathbf{S}}_{T}=\frac{1}{T} \sum_{t} \mathbf{Z}_{\mathbf{t}}{ }^{\prime}{ }_{0} \mathbf{Z}_{\mathbf{t}}+\sum_{j=1}^{K}\left[1-\frac{j}{K+1}\right]\left(\sum_{t=j+1}^{T}\left(\mathbf{Z}_{\mathbf{t}-\mathbf{j}}{ }^{\prime}{ }_{j} \mathbf{Z}_{\mathbf{t}}+\mathbf{Z}_{\mathbf{t}}{ }^{\prime}{ }_{-}{ }_{-j} \mathbf{Z}_{\mathbf{t}-\mathbf{j}}\right)\right) .
$$

Given the small time dimension in our sample, the small sample properties of the estimator in this environment are questionable (see below). As a result, we restrict the non-diagonal terms of $\hat{{ }}{ }_{j}$ to be identical:

$$
\hat{-{ }_{j}}=\left[\begin{array}{cccc}
\hat{\sigma}_{11, j} & \hat{\sigma}_{j} & \cdots & \hat{\sigma}_{j} \\
\hat{\sigma}_{j} & \hat{\sigma}_{22, j} & \cdots & \hat{\sigma}_{j} \\
\vdots & & & \\
\hat{\sigma}_{j} & \hat{\sigma}_{j} & \cdots & \hat{\sigma}_{N N, j}
\end{array}\right] .
$$

This structure greatly reduces the number of parameters in the weighting matrix structure, but retains some of the SUR flavor. When we refer to weighting matrix II in the estimation results section, this restricted form is employed.

- Weighting Matrix III:

This specification facilitates cross-sectional (groupwise) heteroskedasticity, but neither temporal heteroskedasticity nor SUR effects. First, let the non-diagonal terms in $\hat{-}_{j}$ 
equal zero:

$$
\hat{-}_{j}=\left[\begin{array}{cccc}
\hat{\sigma}_{11, j} & 0 & \cdots & 0 \\
0 & \hat{\sigma}_{22, j} & \cdots & 0 \\
\vdots & & & \\
0 & 0 & \cdots & \hat{\sigma}_{N N, j}
\end{array}\right],
$$

where $\hat{\sigma}_{i i, j}$ is defined as follows:

$$
\hat{\sigma}_{i i, j}=\frac{1}{T} \sum_{t=j+1}^{T}\left(\epsilon_{i, t+k, k} \epsilon_{i, t+k-j, k}^{\prime}\right) .
$$

Given the restricted form for $\hat{-}{ }_{j}$, let $\hat{S}_{T}$ be determined as in (21). If GDP growth rates across the countries in our sample are idiosyncratic, then this assumption is plausible.

- Weighting Matrix IV:

The final specification facilitates neither temporal heteroskedasticity, groupwise (countryspecific) heteroskedasticity, nor SUR effects. In this case, the estimated parameters are equivalent to those obtained from a standard pooled OLS estimation methodology, correcting for the MA residual structure. From $\hat{-}_{j}$ defined in (23),

$$
\hat{\sigma}_{j}^{2}=\frac{1}{N} \operatorname{trace}\left(\hat{-}_{j}\right) \forall j .
$$

Then, define the restricted variance covariance matrix in the following manner:

$$
\hat{\mathbf{S}}_{T}=\frac{1}{T} \sum_{t} \hat{\sigma}_{0}^{2} \mathbf{Z}_{\mathbf{t}} \mathbf{Z}_{\mathbf{t}}+\sum_{j=1}^{K}\left[1-\frac{j}{K+1}\right]\left(\sum_{t=j+1}^{T}\left(\hat{\sigma}_{j}^{2} \mathbf{Z}_{\mathbf{t}-\mathbf{j}}{ }^{\prime} \mathbf{Z}_{\mathbf{t}}+\hat{\sigma}_{-j}^{2} \mathbf{Z}_{\mathbf{t}} \mathbf{Z}_{\mathbf{t}-\mathbf{j}}\right)\right) .
$$

Given the construction of the weighting matrix as in one of the preceeding specifications, the GMM estimator is as follows:

$$
\hat{\beta}_{G M M}=\left[\left(\mathbf{X}^{\prime} \mathbf{Z}\right) \hat{\mathbf{S}}_{T}^{-1}\left(\mathbf{Z}^{\prime} \mathbf{X}\right)\right]^{-1}\left[\left(\mathbf{X}^{\prime} \mathbf{Z}\right) \hat{\mathbf{S}}_{T}^{-1}\left(\mathbf{Z}^{\prime} \mathbf{Y}\right)\right]
$$

The standard errors of $\hat{\beta}_{G M M}$ are determined from the variance-covariance matrix:

$$
T\left[\left[\mathbf{X}^{\prime} \mathbf{Z}\right] \hat{\mathbf{S}}_{T}^{-1}\left[\mathbf{Z}^{\prime} \mathbf{X}\right]\right]^{-1}
$$




\subsection{Monte Carlo Experiment}

We explore the finite-sample properties of the GMM estimator in this economic environment. We consider three separate Monte Carlo experiments, one for each of the latter three weighting matrix specifications, II, III and IV detailed above. We also started an experiment using the more general SUR specification of weighting matrix II in (20) but the finite sample properties of the estimator were quite poor.

\subsubsection{Explanatory Variables}

The first step of the Monte Carlo exercise is to generate the right hand side variables, $\mathbf{x}_{i, t}$. The first element of $\mathbf{x}_{i, t}$ is the logged initial real per capita GDP. We first identify the range for this variable in the observed data, and then draw a simulated initial GDP from a uniform distribution over this range for every country.

For the other right hand side variables, we follow a very different strategy. The macroeconomic and financial variables demonstrate significant serial and cross-correlation. We fit a restricted VAR to the following variables: Government consumption to GDP ratio, Trade to GDP ratio, Inflation, secondary school enrollment, Private credit to GDP ratio, market capitalization to GDP ratio, the logged number of domestic companies, and turnover. These are the control variables that we consider in our most general specification. As the time dimension, $T$, is small in our sample, we restrict the VAR coefficients to be identical across countries, but we allow for country specific intercepts. The restricted coefficient matrix,

reported in Appendix Table A, is estimated using pooled OLS. (We also report the standard errors of the restricted VAR.) Given the restricted VAR coefficients, for each country we begin the variables at their unconditional means from the observed data. We simulate $100+$ $T$ values from the VAR for each country, and discard the initial 100 simulated observations. Now, we have simulated observations for the right hand side variables, $\mathbf{x}_{i, t}$, excluding the official liberalization indicator, to which we turn to below. 


\subsubsection{The Dependent Variable}

The real per capita GDP growth is determined according to the model as a function of the right hand side variables, $\mathbf{x}$ and the residuals, $\epsilon$. The null model is as follows:

$$
\tilde{y}_{i, t+k, k}=\beta^{\prime} \tilde{\mathbf{x}}_{i, t}+\tilde{\epsilon}_{i, t+k, k},
$$

with no official liberalization indicator included in the right hand side variables. The $\beta$ vector comes from our growth model specification prior to introducing the indicator variables presented in Table 7. As there are three separate Monte Carlo designs, that is, one for each of the three weighting matrices under consideration, $\beta$ is chosen from Table 7 for each of the three to reflect the particular weighting matrix under consideration. Given the use of overlapping data, the residuals follow an $\mathrm{MA}(k-1)$ process. To mimic this environment, we estimate a restricted $\mathrm{MA}(k-1)$ model for each of the residuals from the estimations performed in Table 7, depending upon the length $k$. The restriction lies in the fact that we jointly estimate the MA $(k-1)$ process for each country, restricting the MA coefficients to be identical across countries. This restriction is motivated in precisely the same way the VAR's are restricted given the limited time series dimension. The restricted MA coefficients, reported in Table A for $k=2, \ldots, 5$, are estimated using quasi-maximum likelihood (QMLE) which assumes uncorrelated errors across countries and normal shocks in the likelihood function. Then, we construct the simulated residuals as follows:

$$
\tilde{\epsilon}_{i, t+k, k}=\sigma_{i}\left(\sum_{j=0}^{k-1} \theta_{j} u_{t+k-j, i}\right),
$$

where the $u_{t+k-j, i}$ are drawn from a standard normal distribution, $\sigma_{i}$ is the estimated standard deviation for country $i$ (given as the sample standard deviation of the residuals from the regressions reported in Table 7), and the $\theta_{j}$ are the cross-sectionally restricted MA coefficients, where $\theta_{0}=1 .{ }^{4}$ Notice that the error terms are independent of the right-hand side control variables.

\footnotetext{
${ }^{4}$ One extension is to allow the errors to be correlated. This would better reflect the SUR estimation structure, whereas the groupwise heteroskedasticity estimation structure is related to $\sigma_{i}$.
} 


\subsubsection{Official Liberalization Indicator}

The construction of the liberalization indicator is very important to our Monte Carlo design. We generate series for each country that are zeros and ones, to mimic the properties of the observed liberalization indicator. First, we generate simulated liberalization dates drawn from a uniform distribution over the time series dimension, i.e. from 1 to $T$, for each country, so that each economy, as in our observed sample, liberalizes at some random time in our simulated sample. Then, the liberalization indicator values for that country are fixed at zeros prior to the simulated liberalization date and ones thereafter.

The next step is to estimate the model:

$$
\tilde{y}_{i, t+k, k}=\beta^{\prime} \tilde{\mathbf{x}}_{i, t}^{\star}+\tilde{\epsilon}_{i, t+k, k}
$$

where $\tilde{\mathbf{x}}_{\mathbf{i}, \mathbf{t}}^{\star}$ includes both the original control variables, $\tilde{\mathbf{x}}_{\mathbf{i}, \mathbf{t}}$, and the liberalization indicator. We retain the estimated coefficient on the liberalization indicator and the corresponding $t$-statistic. Under the null hypothesis of the constructed Monte Carlo model, this coefficient should not be significantly different from zero. We perform this procedure a total of 1000 times, for each of the three weighting matrix specifications. As can be seen in Appendix Table B, we report the summary statistics for the estimated coefficient and the $t$-statistic. For weighting matrix IV, the asymptotic distribution appears to be a good approximation to the Monte Carlo distribution for the $t$-statistic. For weighting matrices III and IV, there appears to be some excess kurtosis in the $t$-statistic, indicating some differences from the asymptotic distribution. For all statistics, the small sample distribution is more dispersed than the normal distribution. We also report the $2.5 \%$ and $97.5 \%$ percentiles for comparison with the critical values we obtain in our regression specifications. For weighting matrices III and IV, these values are substantially larger than the \pm 1.96 implied by the normal critical values. This indicates that $5 \%$ statistical significance is only reached for t-statistics larger than three (when $k$ is larger than one). In all, the Monte Carlo analysis demonstrates that this econometric methodology is a reasonable strategy to evaluate the effect of liberalizations on GDP growth, provided we account for the finite-sample nature of the econometric environment. 


\section{Empirical Results}

\subsection{The Liberalization Effect Without Control Variables}

Table 4 presents our estimates of the relation between real economic growth rates at various horizons and an official liberalization indicator and initial real per capita GDP without any additional control variables. Effectively, this is analogous to exploring the mean growth rate before and after financial liberalization. Consistent with the evidence on the pre and post-liberalization average growth rates presented in Section 2, these estimates demonstrate a positive and statistically significant relation between financial liberalization and economic growth across a variety of specifications and horizons.

In each case, the estimated coefficient is presented when the GMM weighting matrix is constructed as in either specification II, III or IV in the previous section. Specification II is the most general that we consider in that it allows for cross-sectional heteroskedasticity and (restricted) SUR effects, whereas the latter two are more restricted versions. Regardless of weighting matrix specification, the estimated coefficient is positive and significant in all cases. The evidence implies that real GDP per capita growth rates increase following financial liberalization by anywhere from $1.5 \%$ to as large as $2.3 \%$ per annum, on average. For example, with a three-year horizon using weighting matrix II, the impact on real economic growth rates is $2.0 \%$. The evidence presented in Table 4 suggests that, on average, real economic growth rates increase roughly $1.9 \%$ per annum following financial liberalization.

Next, we present evidence on how this relation changes when additional variables are employed to control for various phenomena unrelated to the financial liberalization. Interestingly, the initial GDP appear to be positively related to the level of economic growth, in contrast to the convergence theory; however, much like the purely cross-sectional growth regressions, this relationship will change dramatically as additional control variables are added, lending credence to the concept of "conditional convergence" presented in Barro (1997). ${ }^{5}$

\footnotetext{
${ }^{5}$ The control variables potentially capture the differing steady state growth rates across countries, and convergence is defined relative to these differing steady states. See Barro (1997).
} 


\subsection{Allowing For Control Variables}

The shortcoming of exploring the changes in real economic growth rates before and after financial liberalization is that the observed change may be related to various economic and political phenomena unrelated to the financial liberalization. For example, periods of financial liberalization may be contemporaneous with periods of political reform or economic restructuring. When estimating the relation between growth and financial liberalization, it is important to account for these potentially confounding effects. Consequently, we develop a hierarchical estimation strategy that evaluates the ability of incrementally increasing control groups to explain the cross-sectional and time-series characteristics of real economic growth.

First, we begin by estimating the relation between economic growth rates and several macroeconomic variables that are commonly employed in the literature to explain crosssectional differences. Second, given the evidence presented in King and Levine (1993), we then add control variables which represent banking development. Third, we add equity market variables. These control variables encompass many of the variables deemed important in explaining the cross-section of economic growth rates in Atje and Jovanovic (1993) and Levine and Zervos (1998). Finally in section 4.3, we add the official liberalization indicator, and reexamine the relation between financial liberalization and economic growth having controlled for unrelated effects using variables employed frequently in the literature.

In accordance with our tiered strategy, the first set of regressions we consider involve the use of three macroeconomic conditioning variables and a human capital variable: government consumption as a share of GDP, the size of the trade sector as a share of GDP, the annual inflation rate, and secondary school enrollment.

Table 5 presents evidence on the relation between these variables and economic growth. As before, we present the evidence obtained using the different GMM weighting matrix specifications. While the estimated relation between these variables and real economic growth is not entirely consistent across samples and estimation specifications, several patterns do emerge. First, as in Barro and Sala-i-Martin (1995), high levels of government consumption are negatively (significantly) related to economic growth rates, suggesting that the instabili- 
ties or taxation associated with government consumption are obstacles to economic development. However, this relationship is statistically insignificant for weighting matrix II. Second, the relation between the size of the trade sector and economic growth is statistically weak, and varies across the weighting matrix specifications which is consistent with the results in Edwards (1998) and Rodrik (1999). The relation between inflation and economic growth generally is mostly statistically insignificant and switches signs. Moreover, the measured effect is very small from an economic perspective. Additionally, secondary school enrollment is generally positively and significantly related to economic growth across all weighting matrix specifications. Finally, the relationship between initial GDP and economic growth is negative for weighting matrices II and III, indicating "conditional convergence" once these additional control variables are included.

Based upon the evidence presented in King and Levine (1993), we augment the previous set of conditioning variables by including a measure of banking sector development, the level of private credit as a share of gross domestic product. In Table 6, we present the regressions that include this measure. We find that the relation between the three macroeconomic variables, secondary school enrollment and initial GDP and economic growth is generally unaffected by the inclusion of private credit divided by GDP. Interestingly, the relation between banking sector development and real economic growth is fairly weak. Across the GMM weighting matrix specifications, the relationship is statistically insignificant, which is in sharp contrast to the evidence presented by King and Levine (1993) and Levine and Zervos (1998).

Levine and Zervos (1998) explore the degree to which banking and stock market development explain the cross-sectional characteristics of economic growth. They find that two measures of stock market liquidity are positively related to economic growth, and that stock market and banking development have separate effects upon growth. We employ equity market turnover as our development indicator. Additionally, they find a positive, but statistically weak, relationship between stock market size and GDP growth. We employ the number of domestic companies and the equity market capitalization divided by GDP as measures of stock market size. These variables can also proxy for market development. 
In Table 7, we present the estimated regression coefficients when we add these three measures of equity market development to the control variables presented above, including the measure of banking development. The estimated relation between the macro economic variables and economic growth is qualitatively and quantitatively affected by the inclusion of the three equity market variables. The government/GDP and trade/GDP variables have now generally a larger sign, and are economically and statistically significant. The inflation effect has lost robustness across specifications. The enrollment variable is still important, but its effect is weaker both in an economic and statistical sense. The relation between initial GDP and economic growth is now negative and significant across almost all specifications. Additionally, the measure of banking development is now positively and significantly related to growth at longer horizons, which is consistent with the evidence presented in King and Levine (1993) and Levine and Zervos (1998). The coefficient on equity market size is generally negative and significant which is the opposite to what was expected. Additionally, the relation between the logged number of companies and the rate of economic growth is positive and significant. In accordance with the evidence presented in Levine and Zervos (1998), the relationship between turnover and economic growth is positive and significant in nearly all cases.

\subsection{The Liberalization Effect with Control Variables}

Having potentially controlled for unrelated phenomena by using the macroeconomic, banking sector, and equity market variables employed in the existing growth literature, we return to the relationship between economic growth and financial liberalization, where again the latter is measured using the official liberalization indicator. Table 8 presents the regressions with the financial liberalization indicator and all the control variables. The results in Table 8

show that the estimated relation between the control variables and economic growth are generally unaffected by the inclusion of the liberalization indicator. As before, the relation between economic growth and banking sector development is positive and significant only at longer horizons. The enrollment variable now proves fragile. However, it is striking that across all weighting matrix specifications, financial liberalization is associated with a 
higher level of real economic growth. The evidence implies that real GDP per capita growth rates increase following financial liberalization by anywhere from $0.7 \%$ to as large as $1.4 \%$ per annum. Despite the large Monte Carlo critical values presented in Appendix Table B, these estimates retain statistical significance at the $95 \%$ confidence level in many of the specifications considered.

Overall, the evidence presented in Table 8 suggests that on average real economic growth rates increase roughly $1.1 \%$ per annum following financial liberalization. This finding is consistent with that presented in Table 4, when no control variables are employed, suggesting the relation between financial liberalization and economic growth is robust across weighting matrix specifications and conditioning variables. Levine and Renelt (1992) demonstrate that the estimated coefficients in cross-country regressions require extreme caution in interpretation, as they are sensitive to the set of control variables employed. Consequently, the evidence presented in Table 8 strengthens the argument that financial liberalization explains an important part of the cross-sectional and time-series characteristics of real economic growth.

Surprisingly, the patterns in the coefficients across the different horizons suggest that the strongest growth impacts are experienced shortly after liberalization. For example, for weighting matrix III in Table 8, the coefficients for the one to five year horizons are: 0.0123, $0.0116,0.0118,0.0111$, and 0.0081 . This suggests that the total impact on economic growth over the five year period is $4.1 \%$. Over half of the additional growth $(2.3 \%)$ occurs in the first two years and $87 \%$ of the 5 -year growth impact occurs in the first three years.

\subsection{Robustness}

We explore five experiments that are designed to test the robustness of the liberalization indicator effect on future economic growth.

First, we consider an alternative specification that allows for regional differences in the measured effect of financial liberalization on economic growth. In particular, the high level of economic growth observed in Latin American countries after the debt crisis may significantly affect the relationship between liberalization and growth discussed above. Although this 
higher growth after the "lost decade" may be due in part to financial liberalization, this is open to debate. Therefore, we explore whether Latin American countries drive our results by estimating the following regional regression equation:

$$
y_{i, t+k, k}=\beta^{\prime} \mathbf{x}_{\mathbf{i}, \mathbf{t}}+\delta_{1}\left(\text { lib indicator }_{i} \cdot \operatorname{Latin}_{i}\right)+\delta_{2}\left(\text { lib indicator }_{i} \cdot\left(1-\operatorname{Latin}_{i}\right)\right)+\epsilon_{i, t+k, k},
$$

where $\operatorname{Latin}_{i}$ takes the value of 1 if country $i$ is a Latin American country, and 0 otherwise. This specification allow the relationship between financial liberalization and economic growth to differ across Latin American and non-Latin American countries.

Given the evidence presented in the first panel of Table 9 for these estimated regressions, the regional effect is negligible. If anything, the growth affect appears considerably weaker in Latin American countries relative to other countries. This suggests that the observed liberalization effect discussed above (and presented in Table 8) is not being driven by regional economic success in Latin America during our sample period.

Second, we examine the role of the government sector. Is it the case that the impact of liberalization on economic growth is determined by the size of the government sector? We create a variable, BigGov, that takes on the value of one if the country-specific median government spending to GDP ratio is greater than all countries' median government spending to GDP ratio. We run a regression similar to the regional regression above which splits the liberalization indicator into two pieces.

The results in the Panel B of Table 9 show that the financial liberalization variable retains it significance and magnitude for both sets of countries. The liberalization effect is 25 basis points larger for countries with smaller than median government sectors. However, the difference is not statistically significant. In unreported results, we also estimated a regression adding an interaction term (liberalization times the government sector to GDP ratio). The coefficient on the interaction term was insignificant further strengthening the case that there is no relation between the size of the government sector and the impact of liberalization on real economic growth.

The third experiment examines the role of education. It is possible that countries with higher levels of education could stand to benefit more from financial market liberalizations 
than countries with low levels of education. Similar to the method for the size of the government sector, we created a variable, School, which takes on a value of unity if the country-specific median secondary school enrollment is greater than the whole sample median secondary school enrollment.

The results are presented in Panel $\mathrm{C}$ of Table 9. It is clear from these results that countries with high levels of education stand to benefit more from financial market liberalizations. For example, in the three year horizon for all three weighting matrices, the coefficient on the liberalization indicator is three times larger for countries with above median education levels. The results suggest that policy makers should not expect a large growth impact from liberalization if the country's education level is lower than the median in these 30 emerging markets. The Wald tests show that the difference between the two liberalization effects is statistically significant in the longer horizon regressions.

The fourth experiment focuses on early versus late liberalizers. Is it the case that most of the growth benefits occurred for the early liberalizers? This is possible if only limited capital from the developed world is available and that it has been exhausted by the early liberalizers. Given that the median liberalization date is 1991, we created an additional variable that identifies early versus late liberalizers. Regressions were run that split the liberalization variable into these two categories.

The results are presented in Panel D of Table 9. It is not the case that early liberalizations have more impact than late liberalizations. While the differences are small, the effect goes the other way. For most of the regressions, the late liberalization countries have a greater impact on economic growth. However, early liberalization still leads to a significant statistical and economic growth effect. The difference between the two effects is not statistically significant because the standard errors for the late liberalization countries are large due to the smaller number of observations available to estimate this coefficient.

The final experiment concerns the relation between the financial control variables and liberalizations. In particular, there are reasons to believe that market capitalization to GDP, the number of stocks in the index, and stock turnover, could be impacted by financial liberalization. Indeed, Bekaert and Harvey (2000), show that one of these variables, the 
number of stocks in the index, is significantly higher after liberalizations. The changes in the control variables could confound our analysis linking liberalization and real economic growth. Therefore, in the final panel in Table 9 we report estimates of the growth regression without any financial control variables. The significance for the coefficient on the liberalization indicator is not impacted if the financial variables are dropped from the regression and its magnitude drops by only 14 (31) basis points at the five (three) year horizons.

\section{Conclusions}

The goal of the paper is to explore the relation between financial liberalization and real economic growth. While considerable effort in the past has been expended on the economic and financial fundamentals that explain the cross-section of economic growth, we focus on financial liberalizations. We emphasize the time-series component of growth in addition to the cross-sectional relation. Our results suggest that financial market liberalizations are associated with higher real growth, in the range of one percent per annum. The impact of financial market liberalizations is robust to the inclusion of the usual set of control variables representing the macroeconomic environment, banking development and stock market development. In addition, the relationship between real economic growth and liberalization is not impacted if we control for the size of the government sector or examine early versus late liberalizers. We also find evidence that the impact of liberalization on growth is not a Latin American phenomena. We do find, however, that countries with a higher than average level of education, benefit much more from financial liberalization.

Although our empirical results are intriguing, they warrant further analysis. First, we have focused only on emerging financial markets. In the standard cross-sectional growth literature, larger cross-sections are used including developed countries. Second, dating financial liberalization is problematic (see Bekaert, Harvey, and Lumsdaine (1999)), and we should consider further robustness checks on the financial liberalization dates we consider. ${ }^{6}$ Finally,

\footnotetext{
${ }^{6}$ We performed one robustness check reestimating the model without control variables using the 16 countries that Bekaert and Harvey (2000) show have breaks in their net capital flows. The results using this alternative indicator of liberalization are broadly consistent with what we have reported.
} 
the results remain inherently empirical. How do financial liberalizations result in higher economic growth? Bekaert and Harvey (2000) and Henry (2000a and 2000b) provide evidence that the cost of capital may have decreased and investment increased after capital market liberalization. Comparing Tables 7 and 8 reveals that the turnover coefficient decreases when the liberalization indicator is introduced, suggesting perhaps a liquidity/efficiency mechanism for enhanced growth. Our new research, Bekaert, Harvey and Lundblad (2001), begins to carefully examine all of these important questions. 


\section{Data Appendix}

In the system estimation described in econometric methodology section, all data are employed at the annual frequency.

GDP growth. Growth of real per capita gross domestic product. Available for all countries from 1980 through 1997 from the World Bank Development Indicators CD-ROM.

Trade. Trade is the sum of exports and imports of goods and services measured as a share of gross domestic product. Available for all countries from 1980 through 1997 from the World Bank Development Indicators CD-ROM.

Government Consumption. Government Consumption divided by gross domestic product. General government consumption includes all current expenditures for purchases of goods and services by all levels of government, excluding most government enterprises. It also includes capital expenditure on national defense and security. Available for all countries from 1980 through 1997 from the World Bank Development Indicators CD-ROM.

Inflation. Inflation as measured by the annual growth rate of the gross domestic product implicit deflator. Available for all countries from 1980 through 1997 from the World Bank Development Indicators CD-ROM.

Secondary School Enrollment. Secondary School Enrollment Ratio is the ratio of total enrollment, regardless of age, to the population of the age group that officially corresponds to the level of education shown. Available for all countries from 1980 through 1997 from the World Bank Development Indicators CD-ROM.

Private Credit. Private credit divided by gross domestic product. Credit to private sector refers to financial resources provided to the private sector, such as through loans, purchases of non-equity securities, and trade credits and other accounts receivable that establish a claim for repayment. Available for all countries from 1980 through 1997 from the World Bank Development Indicators CD-ROM.

Market Capitalization. Equity market capitalization divided by gross domestic product. Equity market capitalization is from the International Finance Corporation's Emerging Stock Markets Factbook. The gross domestic product data are from the World Bank Development Indicators CD-ROM. Data are available from 1980 through 1997.

Number of Companies. The log of the number of domestic companies covered taken from the International Finance Corporation's (IFC) Emerging Stock Markets Factbook. The data are available from 1980 through 1997.

Turnover. The ratio of equity market value traded to the market capitalization. Both are available from the International Finance Corporation's Emerging Stock Markets Factbook. The data are available from 1980 through 1997.

Official Liberalization Indicator. The variable takes a value of one when the equity market is liberalized, and zero otherwise. Liberalization dates are based upon the chronology presented in Bekaert and Harvey (2000) for the markets covered by the International Finance Corporation's Global Indices. The dates are presented in Table 1. 


\section{References}

Atje, R., and B. Jovanovic, 1993, "Stock Markets and Development," European Economic Review, 37, 632-640.

Barro, R., 1991, "Economic Growth in a Cross Section of Countries," The Quarterly Journal of Economics, 56, 407-443.

Barro, R., 1997, Determinants of Economic Growth, MIT Press, Cambridge, MA, 1 edn.

Barro, R., and X. S. i Martin, 1995, Economic Growth, McGraw-Hill, New York, NY, 1 edn.

Bekaert, G., and C. Harvey, 1995, "Time-varying World Market Integration," Journal of Finance, 50, 403-444.

Bekaert, G., and C. Harvey, 1997, "Emerging Equity Market Volatility," Journal of Financial Economics, 43, 29-77.

Bekaert, G., and C. Harvey, 2000, "Foreign Speculators and Emerging Equity Markets," Journal of Finance, 55, 565-614.

Bekaert, G., C. Harvey, and R. Lumsdaine, 1999, "Dating the Integration of World Capital Markets," Working Paper, Columbia University and Duke University.

Bekaert, G., C. Harvey, and C. Lundblad, 2001, "Does Financial Liberalization Spur Growth," Working Paper, Columbia University and Duke University.

Edwards, S., 1998, "Openness, Productivity, and Growth: What Do We Really Know?," The Economic Journal, 108, 383-398.

Erb, C., C. Harvey, and T. Viskanta, 1996, "Political Risk, Economic Risk and Financial Risk," Financial Analysis Journal, November/December, 29-46.

Hansen, L., 1982, "Large Sample Properties of Generalized Method of Moments Estimators," Econometrica, 50, 1029-1054.

Harrison, A., 1996, "Openness and Growth: A Time-Series, Cross-Country Analysis for Developing Countries," Journal of Development Economics, 48, 419-447.

Henry, P., 2000a, "Do Stock Market Liberalizations Cause Investment Booms," forthcoming, Journal of Financial Economics.

Henry, P., 2000b, "Stock Market Liberalization, Economic Reform, and Emerging Market Equity Prices," Journal of Finance, 55, 529-564.

IFC, 1997, Emerging Stock Markets Factbook 1997, International Finance Corporation, Washington, D.C. 
Islam, N., 1995, "Growth Empirics: A Panel Data Approach," The Quarterly Journal of Economics, 107, 1127-1170.

King, R., and R. Levine, 1993, "Finance and Growth: Schumpeter Might Be Right," The Quarterly Journal of Economics, 108, 717-738.

Levine, R., and D. Renelt, 1992, "A Sensitivity Analysis of Cross-Country Growth Regressions," The American Economic Review, 82, 942-963.

Levine, R., and S. Zervos, 1998, "Stock Markets, Banks, and Economic Growth," The American Economic Review, 88, 537-558.

Newey, W., and K. West, 1987, "A Simple, Positive Semi-Definite, Heteroskedasticity and Autocorrelation Consistent Covariance Matrix," Econometrica, 55, 703-708.

Obstfeld, M., 1994, "Risk Taking, Global Diversification and Growth," The American Economic Review, 84, 1310-1329.

Rodrik, D., 1999, Determinants of Economic Growth, Overseas Development Council, Washington, DC. 
Figure 1

Real Economic Growth

Before and After Financial Liberalizations

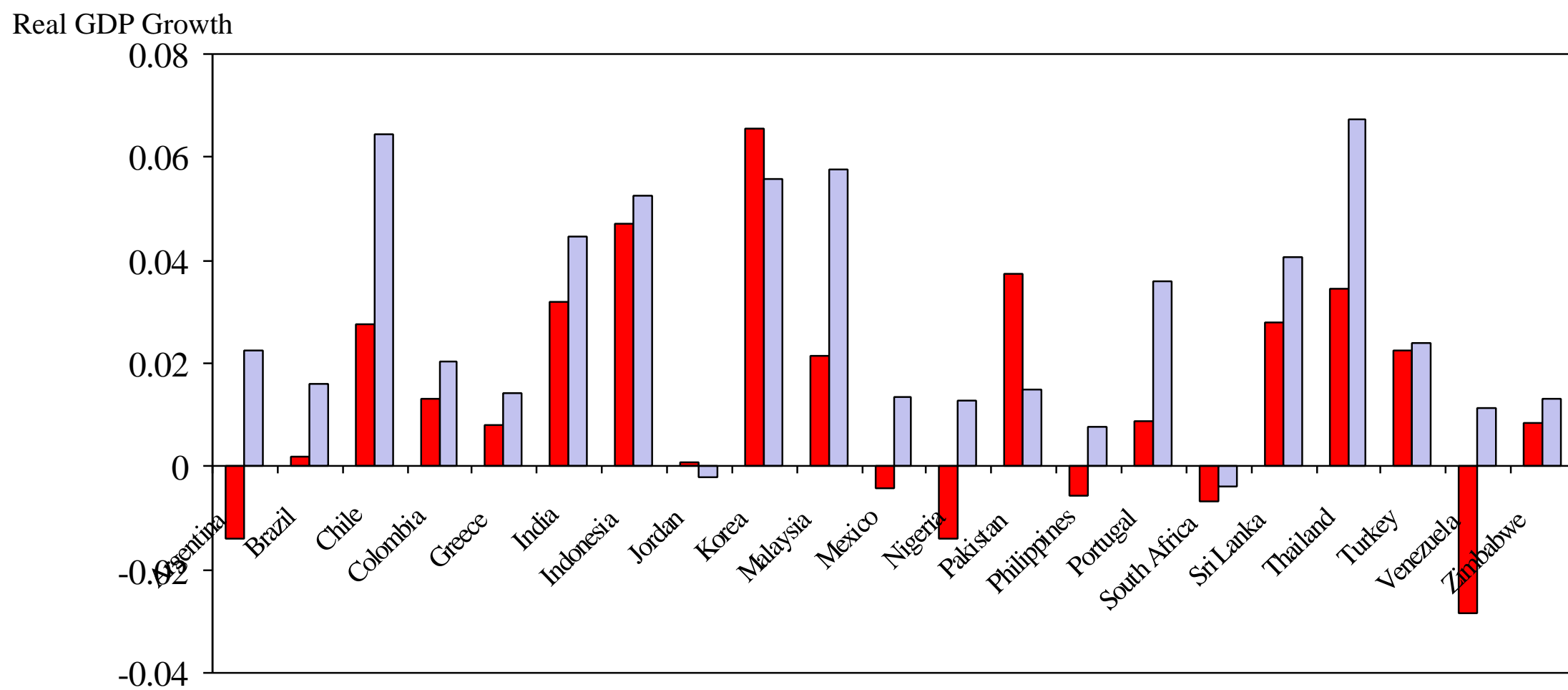

$\square$ Pre-liberalization $\square$ Post-liberalization

Liberalization dates from Bekaert and Harvey (2000). 
Table 1

Sample Specification

1980-1997 (30 countries)

\begin{tabular}{|c|c|c|c|}
\hline Country & Liberalization & Country & Liberalization \\
\hline Argentina & 1989 & Malaysia & 1988 \\
\hline Bangladesh & NL & Mexico & 1989 \\
\hline Brazil & 1991 & Morocco & 1997 \\
\hline Chile & 1992 & Nigeria & 1995 \\
\hline Colombia & 1991 & Pakistan & 1991 \\
\hline Cote d'Ivoire & NL & Philippines & 1991 \\
\hline Egypt, Arab Rep. & 1997 & Portugal & 1986 \\
\hline Greece & 1987 & Sri Lanka & 1992 \\
\hline India & 1992 & South Africa & 1992 \\
\hline Indonesia & 1989 & Thailand & 1987 \\
\hline Israel & 1996 & Trinidad and Tobago & NL \\
\hline Jamaica & NL & Tunisia & NL \\
\hline Jordan & 1995 & Turkey & 1989 \\
\hline Kenya & NL & Venezuela & 1990 \\
\hline Korea, Rep. & 1992 & Zimbabwe & 1993 \\
\hline
\end{tabular}

$\overline{\text { These countries are classified as emerging }}$ or frontier by the International Finance Corporation. Most of the liberalization dates are from Bekaert and Harvey (2000). In addition, we designate a liberalization when the IFC Frontier market is included into the IFC global index group.

NL refers to not liberalized. 
Table 2

Summary statistics for macroeconomic variables

Bangla- Cote Egypt, Korea, \begin{tabular}{lllllllllll} 
Argentina & desh & Brazil & Chile & Colombia & d'Ivoire Arab Rep. & Greece & India & Indonesia & Israel Jamaica Jordan & Kenya \\
\hline
\end{tabular} Real per capita GDP growth (annual) US\$

\section{0-1989}

\begin{tabular}{|c|c|c|c|c|c|c|c|c|c|c|c|c|c|c|c|}
\hline Mean & -0.021 & 0.017 & 0.008 & 0.025 & 0.012 & -0.039 & 0.032 & 0.012 & 0.036 & 0.043 & 0.018 & 0.001 & -0.001 & 0.005 & 0.063 \\
\hline Std. dev. & 0.051 & 0.022 & 0.047 & 0.064 & 0.015 & 0.049 & 0.025 & 0.018 & 0.018 & 0.024 & 0.021 & 0.045 & 0.081 & 0.020 & 0.043 \\
\hline \multicolumn{16}{|l|}{ 1990-1997 } \\
\hline Mean & 0.036 & 0.032 & 0.006 & 0.058 & 0.020 & -0.004 & 0.020 & 0.011 & 0.036 & 0.056 & 0.024 & -0.001 & 0.003 & -0.006 & 0.061 \\
\hline Std. dev. & 0.052 & 0.010 & 0.034 & 0.025 & 0.014 & 0.036 & 0.016 & 0.013 & 0.024 & 0.012 & 0.015 & 0.022 & 0.056 & 0.020 & 0.016 \\
\hline \multicolumn{16}{|l|}{ 1980-1997 } \\
\hline Mean & 0.004 & 0.023 & 0.007 & 0.040 & 0.016 & -0.024 & 0.027 & 0.012 & 0.036 & 0.049 & 0.021 & 0.000 & 0.000 & 0.000 & 0.062 \\
\hline Std. dev. & 0.058 & 0.019 & 0.040 & 0.052 & 0.015 & 0.046 & 0.021 & 0.015 & 0.020 & 0.020 & 0.018 & 0.036 & 0.069 & 0.020 & 0.033 \\
\hline
\end{tabular}

Inflation 1980-1997

\begin{tabular}{llllllllllllllll}
\cline { 2 - 31 } Mean & 4.548 & 0.083 & 6.502 & 0.179 & 0.237 & 0.068 & 0.151 & 0.166 & 0.094 & 0.091 & 0.777 & 0.233 & 0.065 & 0.155 & 0.074 \\
Std. dev. & 8.506 & 0.041 & 8.696 & 0.082 & 0.040 & 0.064 & 0.052 & 0.057 & 0.024 & 0.176 & 0.062 & 0.105 & 0.068 \\
\hline
\end{tabular}

$\underline{\text { Trade/GDP 1980-1997 }}$

\begin{tabular}{lccccccccccccccc}
\cline { 2 - 26 } Std. dev. & 0.156 & 0.211 & 0.177 & 0.556 & 0.311 & 0.700 & 0.558 & 0.420 & 0.191 & 0.499 & 0.872 & 1.113 & 1.245 & 0.589 & 0.676 \\
& 0.022 & 0.043 & 0.022 & 0.074 & 0.040 & 0.095 & 0.115 & 0.025 & 0.046 & 0.040 & 0.100 & 0.160 & 0.171 & 0.089 & 0.064 \\
\hline
\end{tabular}

$\underline{\text { Govt/GDP 1980-1997 }}$

\begin{tabular}{lccccccccccccccc}
\cline { 2 - 26 } Std. dev. & 0.066 & 0.033 & 0.140 & 0.114 & 0.116 & 0.156 & 0.137 & 0.140 & 0.109 & 0.094 & 0.327 & 0.159 & 0.259 & 0.173 & 0.105 \\
& 0.037 & 0.011 & 0.042 & 0.019 & 0.022 & 0.021 & 0.033 & 0.009 & 0.008 & 0.015 & 0.044 & 0.031 & 0.021 & 0.015 & 0.006 \\
\hline
\end{tabular}

Enrollment 1980-1997

\begin{tabular}{|c|c|c|c|c|c|c|c|c|c|c|c|c|c|c|c|}
\hline $\begin{array}{l}\text { Mean } \\
\text { Std. dev. }\end{array}$ & $\begin{array}{l}0.226 \\
0.023 \\
\end{array}$ & $\begin{array}{l}0.198 \\
0.016 \\
\end{array}$ & $\begin{array}{c}0.203 \\
0.022 \\
\end{array}$ & $\begin{array}{l}0.199 \\
0.043 \\
\end{array}$ & $\begin{array}{c}0.175 \\
0.016 \\
\end{array}$ & $\begin{array}{l}0.136 \\
0.052 \\
\end{array}$ & $\begin{array}{l}0.238 \\
0.057 \\
\end{array}$ & $\begin{array}{l}0.225 \\
0.029 \\
\end{array}$ & $\begin{array}{l}0.216 \\
0.016 \\
\end{array}$ & $\begin{array}{c}0.258 \\
0.022 \\
\end{array}$ & $\begin{array}{l}0.213 \\
0.022 \\
\end{array}$ & $\begin{array}{l}0.257 \\
0.067 \\
\end{array}$ & $\begin{array}{l}0.285 \\
0.066 \\
\end{array}$ & $\begin{array}{l}0.195 \\
0.018 \\
\end{array}$ & $\begin{array}{l}0.326 \\
0.038 \\
\end{array}$ \\
\hline $\mathrm{vC}$ & $0-1997$ & & & & & & & & & & & & & & \\
\hline $\begin{array}{l}\text { Mean } \\
\text { Std. dev. }\end{array}$ & $\begin{array}{l}0.212 \\
0.068\end{array}$ & $\begin{array}{l}0.118 \\
0.063\end{array}$ & $\begin{array}{l}0.493 \\
0.183\end{array}$ & $\begin{array}{l}0.488 \\
0.209\end{array}$ & $\begin{array}{l}0.292 \\
0.085\end{array}$ & $\begin{array}{l}0.340 \\
0.072\end{array}$ & $\begin{array}{l}0.293 \\
0.083\end{array}$ & $\begin{array}{l}0.395 \\
0.046\end{array}$ & $\begin{array}{l}0.254 \\
0.065\end{array}$ & $\begin{array}{l}0.296 \\
0.167\end{array}$ & $\begin{array}{l}0.615 \\
0.110\end{array}$ & $\begin{array}{l}0.307 \\
0.054\end{array}$ & $\begin{array}{l}0.602 \\
0.155\end{array}$ & $\begin{array}{l}0.295 \\
0.042\end{array}$ & $\begin{array}{l}0.572 \\
0.121\end{array}$ \\
\hline
\end{tabular}


Table 2 (continued)

Summary statistics for macroeconomic variables

\begin{tabular}{|c|c|c|c|c|c|c|c|c|c|c|c|c|c|c|}
\hline Malaysia & Mexico & Morocco & Nigeria & Pakistan & $\begin{array}{r}\text { Phili- } \\
\text { ppines }\end{array}$ & Portugal & $\begin{array}{l}\text { South } \\
\text { Africa }\end{array}$ & Sri Lanka & Thailand & $\begin{array}{r}\text { Trinidad } \\
\text { and } \\
\text { Tobago } \\
\end{array}$ & Tunisia & Turkey & $\begin{array}{r}\text { Venez- } \\
\text { uela } \\
\end{array}$ & $\begin{array}{r}\text { Zim- } \\
\text { babwe }\end{array}$ \\
\hline \multicolumn{15}{|c|}{ a GDP growth (annual) US\$ } \\
\hline 0.028 & -0.002 & 0.021 & -0.024 & 0.039 & -0.007 & 0.029 & -0.002 & 0.026 & 0.052 & -0.010 & 0.010 & 0.018 & -0.028 & 0.017 \\
\hline 0.032 & 0.057 & 0.049 & 0.075 & 0.014 & 0.052 & 0.031 & 0.039 & 0.013 & 0.030 & 0.056 & 0.032 & 0.030 & 0.049 & 0.050 \\
\hline 0.058 & 0.012 & 0.004 & 0.008 & 0.015 & 0.007 & 0.025 & -0.010 & 0.040 & 0.058 & 0.011 & 0.030 & 0.030 & 0.011 & 0.001 \\
\hline 0.006 & 0.040 & 0.067 & 0.026 & 0.023 & 0.023 & 0.017 & 0.021 & 0.010 & 0.032 & 0.072 & 0.022 & 0.050 & 0.038 & 0.056 \\
\hline 0.041 & 0.005 & 0.013 & -0.010 & 0.029 & -0.001 & 0.027 & 0.032 & -0.006 & 0.055 & -0.001 & 0.019 & 0.023 & -0.011 & 0.010 \\
\hline 0.028 & 0.050 & 0.057 & 0.059 & 0.022 & 0.041 & 0.025 & 0.014 & 0.031 & 0.030 & 0.062 & 0.029 & 0.039 & 0.048 & 0.052 \\
\hline
\end{tabular}

Inflation 1980-1997

\begin{tabular}{lccccccccccccccc}
\cline { 2 - 7 } Mean & 0.037 & 0.479 & 0.065 & 0.289 & 0.089 & 0.128 & 0.128 & 0.126 & 0.129 & 0.055 & 0.095 & 0.069 & 0.631 & 0.358 & 0.180 \\
Std. dev. & 0.023 & 0.378 & 0.034 & 0.222 & 0.029 & 0.108 & 0.079 & 0.057 & 0.032 & 0.043 & 0.041 & 0.019 & 0.247 & 0.265 & 0.087 \\
\hline
\end{tabular}

Trade/GDP 1980-1997

\begin{tabular}{lccccccccccccccc}
\cline { 2 - 22 } Mean & 1.400 & 0.366 & 0.550 & 0.588 & 0.350 & 0.622 & 0.685 & 0.714 & 0.508 & 0.671 & 0.787 & 0.842 & 0.341 & 0.491 & 0.534 \\
Std. dev. & 0.329 & 0.122 & 0.041 & 0.219 & 0.020 & 0.169 & 0.043 & 0.083 & 0.058 & 0.161 & 0.112 & 0.083 & 0.091 & 0.074 & 0.141 \\
\cline { 2 - 17 }
\end{tabular}

Govt/GDP 1980-1997

\begin{tabular}{lccccccccccccccc} 
Mean & 0.145 & 0.095 & 0.167 & 0.136 & 0.127 & 0.095 & 0.156 & 0.095 & 0.182 & 0.111 & 0.161 & 0.164 & 0.102 & 0.096 & 0.191 \\
Std. dev. & 0.021 & 0.010 & 0.012 & 0.031 & 0.018 & 0.015 & 0.018 & 0.011 & 0.025 & 0.016 & 0.050 & 0.008 & 0.019 & 0.022 & 0.032 \\
\hline
\end{tabular}

Enrollment 1980-1997

\begin{tabular}{llllllllllllllll} 
Mean & 0.341 & 0.195 & 0.225 & 0.178 & 0.152 & 0.227 & 0.270 & 0.251 & 0.207 & 0.336 & 0.196 & 0.265 & 0.210 & 0.192 & 0.184 \\
Std. dev. & 0.061 & 0.026 & 0.020 & 0.044 & 0.016 & 0.040 & 0.036 & 0.029 & 0.043 & 0.062 & 0.050 & 0.039 & 0.048 & 0.033 & 0.034 \\
\cline { 2 - 32 }
\end{tabular}

PrivCredit/GDP 1980-1997

$\begin{array}{lcccccccccccccccc}\text { Mean } & 0.772 & 0.209 & 0.300 & 0.113 & 0.263 & 0.348 & 0.649 & 0.848 & 0.201 & 0.703 & 0.405 & 0.564 & 0.183 & 0.368 & 0.223 \\ \text { Std. dev. } & 0.370 & 0.081 & 0.103 & 0.042 & 0.034 & 0.123 & 0.132 & 0.275 & 0.037 & 0.369 & 0.111 & 0.094 & 0.026 & 0.153 & 0.076\end{array}$

Govt/GDP is the ratio of government consumption to GDP; Trade/GDP is the sum of exports and imports of goods and services measured as a share of GDP; Inflation as measured by the annual growth rate of the GDP implicit deflator or CPI if unavailable; Enrollment is the secondary school enrollment ratio; PrivCredit/GDP is private credit divided by GDP; 
Table 3

Summary statistics for financial variables

\begin{tabular}{|c|c|c|c|c|c|c|c|c|c|c|c|c|c|c|c|}
\hline \multirow[b]{2}{*}{ MCAP/GD } & \multirow[t]{2}{*}{ Argentina } & Bangla-desh & \multirow[t]{2}{*}{ Brazil } & \multirow[t]{2}{*}{ Chile } & \multirow[t]{2}{*}{ Colombia } & \multirow[t]{2}{*}{$\begin{array}{r}\text { Cote } \\
\text { d'Ivoire } \\
\end{array}$} & \multirow[t]{2}{*}{$\begin{array}{r}\text { Egypt, } \\
\text { Arab Rep. }\end{array}$} & \multirow[t]{2}{*}{ Greece } & \multirow[t]{2}{*}{ India } & \multirow[t]{2}{*}{ Indonesia } & \multirow[t]{2}{*}{ Israel } & \multirow[t]{2}{*}{ Jamaica } & \multirow[t]{2}{*}{ Jordan } & \multirow[t]{2}{*}{ Kenya } & \multirow[t]{2}{*}{$\begin{array}{r}\text { Korea, } \\
\text { Rep. }\end{array}$} \\
\hline & & & & & & & & & & & & & & & \\
\hline \multicolumn{16}{|c|}{$1980-1989$} \\
\hline Mean & 0.024 & 0.008 & 0.094 & 0.222 & 0.028 & 0.040 & 0.037 & 0.048 & 0.062 & 0.003 & 0.288 & 0.123 & 0.475 & 0.056 & 0.190 \\
\hline $\begin{array}{l}\text { Std. dev. } \\
\text { 1990-1997 }\end{array}$ & 0.016 & 0.007 & 0.054 & 0.087 & 0.009 & 0.007 & 0.016 & 0.027 & 0.019 & 0.007 & 0.145 & 0.088 & 0.074 & 0.001 & 0.213 \\
\hline Mean & 0.122 & 0.032 & 0.204 & 0.933 & 0.155 & 0.067 & 0.122 & 0.157 & 0.305 & 0.194 & 0.386 & 0.451 & 0.695 & 0.174 & 0.352 \\
\hline $\begin{array}{l}\text { Std. dev. } \\
\text { 1980-1997 }\end{array}$ & 0.052 & 0.035 & 0.110 & 0.291 & 0.066 & 0.028 & 0.081 & 0.034 & 0.101 & 0.129 & 0.222 & 0.250 & 0.120 & 0.123 & 0.124 \\
\hline Mean & 0.067 & 0.019 & 0.143 & 0.538 & 0.084 & 0.052 & 0.075 & 0.096 & 0.170 & 0.088 & 0.332 & 0.269 & 0.573 & 0.108 & 0.262 \\
\hline Std. dev. & 0.061 & 0.026 & 0.098 & 0.413 & 0.078 & 0.023 & 0.069 & 0.063 & 0.141 & 0.128 & 0.184 & 0.241 & 0.147 & 0.099 & 0.193 \\
\hline \multirow{2}{*}{\multicolumn{16}{|c|}{$\frac{\log (\# \text { stocks })}{1980-1989}$}} \\
\hline & & & & & & & & & & & & & & & \\
\hline Mean & 5.417 & 3.983 & 6.272 & 5.403 & 4.890 & 3.185 & 5.379 & 4.744 & 8.264 & 2.939 & 5.410 & 3.662 & 4.540 & 3.994 & 5.945 \\
\hline $\begin{array}{l}\text { Std. dev. } \\
\text { 1990-1997 }\end{array}$ & 0.140 & 0.602 & 0.113 & 0.082 & 0.387 & 0.048 & 0.814 & 0.023 & 0.375 & 0.637 & 0.313 & 0.093 & 0.156 & 0.021 & 0.214 \\
\hline Mean & 5.083 & 5.089 & 6.319 & 5.557 & 4.766 & 3.318 & 6.488 & 5.152 & 8.370 & 5.250 & 6.119 & 3.864 & 4.646 & 4.021 & 6.566 \\
\hline $\begin{array}{l}\text { Std. dev. } \\
\text { 1980-1997 }\end{array}$ & 0.107 & 0.152 & 0.028 & 0.121 & 0.410 & 0.145 & 0.078 & 0.265 & 0.364 & 0.297 & 0.478 & 0.059 & 0.121 & 0.029 & 0.053 \\
\hline Mean & 5.268 & 4.475 & 6.293 & 5.471 & 4.835 & 3.244 & 5.872 & 4.925 & 8.311 & 3.966 & 5.725 & 3.752 & 4.587 & 4.006 & 6.221 \\
\hline Std. dev. & 0.211 & 0.722 & 0.087 & 0.126 & 0.390 & 0.120 & 0.821 & 0.270 & 0.363 & 1.284 & 0.527 & 0.129 & 0.148 & 0.027 & 0.355 \\
\hline \multicolumn{16}{|l|}{$\underline{\text { Turnover }}$} \\
\hline 1980-1989 & & & & & & & & & & & & & & & \\
\hline Mean & 0.267 & 0.008 & 0.502 & 0.057 & 0.100 & 0.028 & 0.064 & 0.041 & 0.495 & 0.091 & 0.524 & 0.065 & 0.122 & 0.022 & 0.692 \\
\hline $\begin{array}{l}\text { Std. dev. } \\
\text { 1990-1997 }\end{array}$ & 0.080 & 0.004 & 0.119 & 0.028 & 0.073 & 0.044 & 0.026 & 0.032 & 0.155 & 0.078 & 0.555 & 0.038 & 0.072 & 0.000 & 0.149 \\
\hline Mean & 0.320 & 0.091 & 0.514 & 0.089 & 0.085 & 0.019 & 0.118 & 0.283 & 0.322 & 0.480 & 0.700 & 0.109 & 0.182 & 0.028 & 1.503 \\
\hline $\begin{array}{l}\text { Std. dev. } \\
\text { 1980-1997 }\end{array}$ & 0.235 & 0.084 & 0.152 & 0.034 & 0.034 & 0.008 & 0.084 & 0.157 & 0.162 & 0.422 & 0.543 & 0.094 & 0.109 & 0.014 & 1.074 \\
\hline Mean & 0.291 & 0.045 & 0.507 & 0.072 & 0.093 & 0.024 & 0.088 & 0.149 & 0.418 & 0.264 & 0.602 & 0.084 & 0.148 & 0.025 & 1.053 \\
\hline Std. dev. & 0.164 & 0.069 & 0.130 & 0.034 & 0.058 & 0.033 & 0.064 & 0.161 & 0.177 & 0.341 & 0.541 & 0.070 & 0.093 & 0.010 & 0.811 \\
\hline
\end{tabular}


Table 3 (continued)

Summary statistics for financial variables

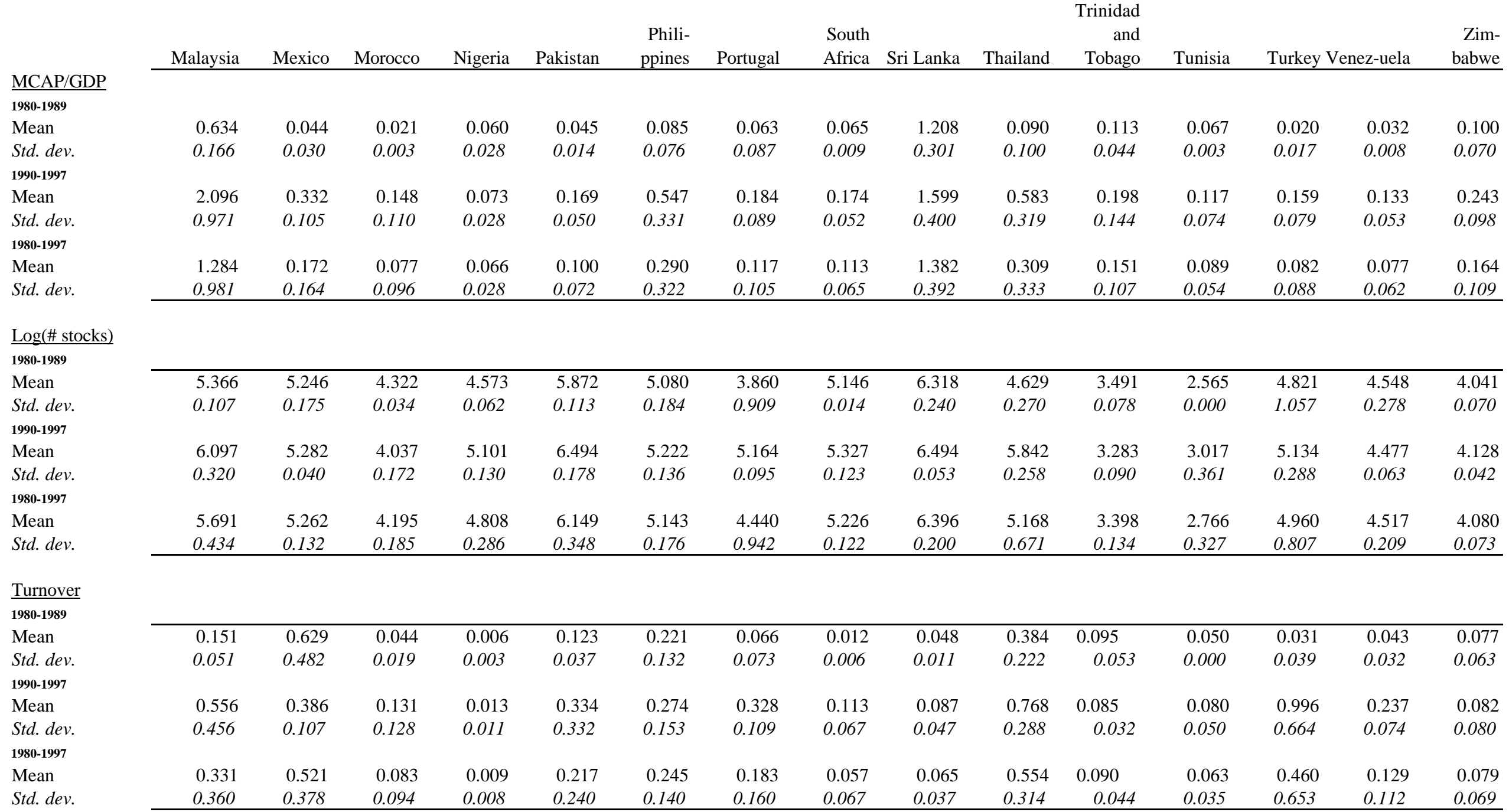

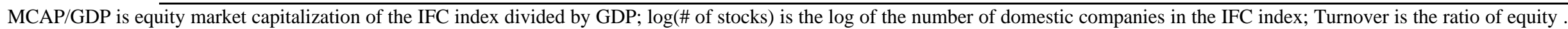
market value traded to the MCAP for the IFC index 
Table 4

Financial liberalization and economic growth - no control variables

30 Countries, 1981-1997

Horizon in years

Weighting matrix

2

\begin{tabular}{lll}
3 & 4 & 5 \\
\hline
\end{tabular}

5

$\mathrm{k}=1$ III 3

$\log (\mathrm{GDP})$
Std. error

$\begin{array}{lllll}0.0015 & 0.0014 & 0.0013 & 0.0013 & 0.0014 \\ 0.0003 & 0.0003 & 0.0004 & 0.0004 & 0.0004 \\ & & & & \\ 0.0201 & 0.0189 & 0.0200 & 0.0194 & 0.0176 \\ 0.0035 & 0.0042 & 0.0051 & 0.0055 & 0.0058\end{array}$

eighting matrix 
Table 5

Macroeconomic control variables and economic growth

30 Countries, 1981-1997

Horizon in years

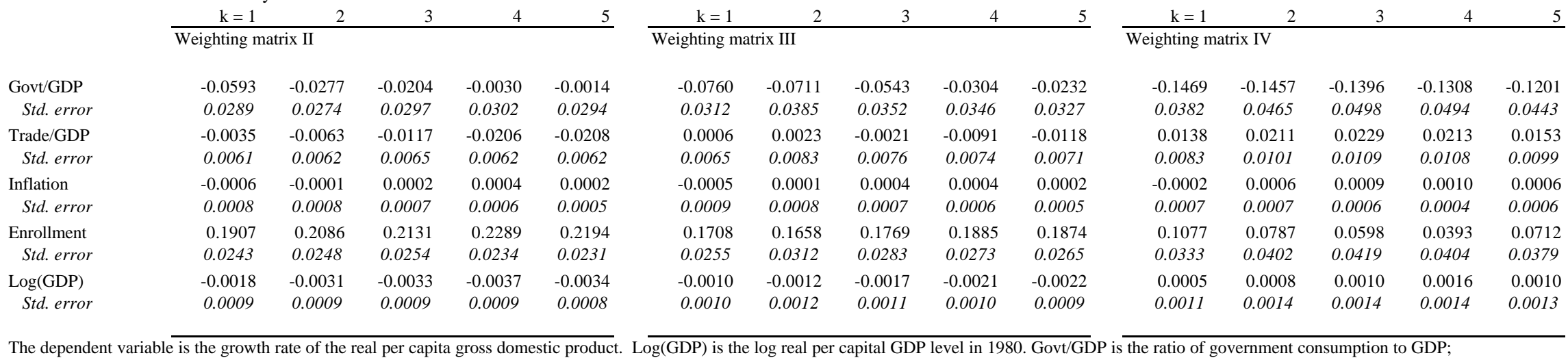

$\mathrm{k}=1$

$\frac{\mathrm{k}=1}{\text { Weighting matrix III }}$

\begin{tabular}{|c|c|c|c|c|c|c|c|c|c|c|c|c|c|c|c|}
\hline $\begin{array}{l}\text { Govt/GDP } \\
\text { Std. error }\end{array}$ & $\begin{array}{c}-0.0593 \\
0.0289\end{array}$ & $\begin{array}{r}-0.0277 \\
0.0274\end{array}$ & $\begin{array}{l}-0.0204 \\
0.0297\end{array}$ & $\begin{array}{c}-0.0030 \\
0.0302\end{array}$ & $\begin{array}{l}-0.0014 \\
0.0294\end{array}$ & $\begin{array}{r}-0.0760 \\
0.0312\end{array}$ & $\begin{array}{l}-0.0711 \\
0.0385\end{array}$ & $\begin{array}{l}-0.0543 \\
0.0352\end{array}$ & $\begin{array}{l}-0.0304 \\
0.0346\end{array}$ & $\begin{array}{r}-0.0232 \\
0.0327\end{array}$ & $\begin{array}{c}-0.1469 \\
0.0382\end{array}$ & $\begin{array}{r}-0.1457 \\
0.0465\end{array}$ & $\begin{array}{c}-0.1396 \\
0.0498\end{array}$ & $\begin{array}{l}-0.1308 \\
0.0494\end{array}$ & $\begin{array}{l}-0.1201 \\
0.0443\end{array}$ \\
\hline $\begin{array}{l}\text { Trade/GDP } \\
\text { Std. error }\end{array}$ & $\begin{array}{r}-0.0035 \\
0.0061\end{array}$ & $\begin{array}{r}-0.0063 \\
0.0062\end{array}$ & $\begin{array}{r}-0.0117 \\
0.0065\end{array}$ & $\begin{array}{c}-0.0206 \\
0.0062\end{array}$ & $\begin{array}{c}-0.0208 \\
0.0062\end{array}$ & $\begin{array}{l}0.0006 \\
0.0065\end{array}$ & $\begin{array}{l}0.0023 \\
0.0083\end{array}$ & $\begin{array}{l}-0.0021 \\
0.0076\end{array}$ & $\begin{array}{r}-0.0091 \\
0.0074\end{array}$ & $\begin{array}{c}-0.0118 \\
0.0071\end{array}$ & $\begin{array}{l}0.0138 \\
0.0083\end{array}$ & $\begin{array}{l}0.0211 \\
0.0101\end{array}$ & $\begin{array}{l}0.0229 \\
0.0109\end{array}$ & $\begin{array}{l}0.0213 \\
0.0108\end{array}$ & $\begin{array}{l}0.0153 \\
0.0099\end{array}$ \\
\hline $\begin{array}{l}\text { Inflation } \\
\text { Std. error }\end{array}$ & $\begin{array}{c}-0.0006 \\
0.0008\end{array}$ & $\begin{array}{r}-0.0001 \\
0.0008\end{array}$ & $\begin{array}{l}0.0002 \\
0.0007\end{array}$ & $\begin{array}{l}0.0004 \\
0.0006\end{array}$ & $\begin{array}{l}0.0002 \\
0.0005\end{array}$ & $\begin{array}{r}-0.0005 \\
0.0009\end{array}$ & $\begin{array}{l}0.0001 \\
0.0008\end{array}$ & $\begin{array}{l}0.0004 \\
0.0007\end{array}$ & $\begin{array}{l}0.0004 \\
0.0006\end{array}$ & $\begin{array}{l}0.0002 \\
0.0005\end{array}$ & $\begin{array}{c}-0.0002 \\
0.0007\end{array}$ & $\begin{array}{l}0.0006 \\
0.0007\end{array}$ & $\begin{array}{l}0.0009 \\
0.0006\end{array}$ & $\begin{array}{l}0.0010 \\
0.0004\end{array}$ & $\begin{array}{l}0.0006 \\
0.0006\end{array}$ \\
\hline $\begin{array}{l}\text { Enrollment } \\
\text { Std. error }\end{array}$ & $\begin{array}{l}0.1907 \\
0.0243\end{array}$ & $\begin{array}{l}0.2086 \\
0.0248\end{array}$ & $\begin{array}{l}0.2131 \\
0.0254\end{array}$ & $\begin{array}{l}0.2289 \\
0.0234\end{array}$ & $\begin{array}{l}0.2194 \\
0.0231\end{array}$ & $\begin{array}{l}0.1708 \\
0.0255\end{array}$ & $\begin{array}{l}0.1658 \\
0.0312\end{array}$ & $\begin{array}{l}0.1769 \\
0.0283\end{array}$ & $\begin{array}{l}0.1885 \\
0.0273\end{array}$ & $\begin{array}{l}0.1874 \\
0.0265\end{array}$ & $\begin{array}{l}0.1077 \\
0.0333\end{array}$ & $\begin{array}{l}0.0787 \\
0.0402\end{array}$ & $\begin{array}{l}0.0598 \\
0.0419\end{array}$ & $\begin{array}{l}0.0393 \\
0.0404\end{array}$ & $\begin{array}{l}0.0712 \\
0.0379\end{array}$ \\
\hline $\begin{array}{l}\log (\mathrm{GDP}) \\
\text { Std. error }\end{array}$ & $\begin{array}{c}-0.0018 \\
0.0009\end{array}$ & $\begin{array}{c}-0.0031 \\
0.0009\end{array}$ & $\begin{array}{r}-0.0033 \\
0.0009\end{array}$ & $\begin{array}{c}-0.0037 \\
0.0009\end{array}$ & $\begin{array}{c}-0.0034 \\
0.0008\end{array}$ & $\begin{array}{r}-0.0010 \\
0.0010\end{array}$ & $\begin{array}{c}-0.0012 \\
0.0012\end{array}$ & $\begin{array}{c}-0.0017 \\
0.0011\end{array}$ & $\begin{array}{c}-0.0021 \\
0.0010\end{array}$ & $\begin{array}{c}-0.0022 \\
0.0009\end{array}$ & $\begin{array}{l}0.0005 \\
0.0011\end{array}$ & $\begin{array}{l}0.0008 \\
0.0014\end{array}$ & $\begin{array}{l}0.0010 \\
0.0014\end{array}$ & $\begin{array}{l}0.0016 \\
0.0014\end{array}$ & $\begin{array}{l}0.0010 \\
0.0013\end{array}$ \\
\hline
\end{tabular}

The dependent variable is the growth rate of the real per capita gross domestic product. $\operatorname{Log(GDP)}$ is the log real per capital GDP level in 1980. Govt/GDP is the ratio of government consumption to GDP;

Trade/GDP is the sum of exports and imports of goods and services measured as a share of GDP; Inflation as measured by the annual growth rate of the GDP implicit deflator; Enrollment is the

secondary school enrollment ratio. Weighing matrix II refers to a correction for cross-sectional heteroskedasticity and SUR effects; weighting matrix III refers to a correction for cross-sectional heteroskedasticity;

and weighting matrix IV refers to a simple pooled OLS. All standard errors are robust, accounting for the overlapping nature of the data. 
Table 6

Macroeconomic and banking control variables and economic growth

30 Countries, 1981-1997

Horizon in years

\begin{tabular}{ccrrr}
$\mathrm{k}=1$ & 2 & 3 & 4 & 5 \\
\hline \multicolumn{2}{l}{ Weighting matrix II } & & & \\
-0.0642 & -0.0340 & -0.0338 & -0.0188 & -0.0227 \\
0.0301 & 0.0290 & 0.0307 & 0.0301 & 0.0277 \\
-0.0022 & -0.0042 & -0.0087 & -0.0176 & -0.0211 \\
0.0062 & 0.0064 & 0.0068 & 0.0064 & 0.0063 \\
-0.0006 & 0.0000 & 0.0002 & 0.0004 & 0.0004 \\
0.0009 & 0.0008 & 0.0007 & 0.0006 & 0.0005 \\
0.1855 & 0.1963 & 0.1960 & 0.2107 & 0.2175 \\
0.0250 & 0.0255 & 0.0263 & 0.0245 & 0.0231 \\
-0.0015 & -0.0028 & -0.0029 & -0.0033 & -0.0033 \\
0.0009 & 0.0009 & 0.0010 & 0.0009 & 0.0009 \\
-0.0022 & 0.0004 & 0.0038 & 0.0084 & 0.0073 \\
0.0077 & 0.0085 & 0.0095 & 0.0097 & 0.0090
\end{tabular}

\begin{tabular}{ccccr}
$\mathrm{k}=1$ & 2 & 3 & 4 & 5 \\
\hline \multicolumn{2}{l}{ Weighting matrix III } & & & \\
-0.0814 & -0.0792 & -0.0661 & -0.0473 & -0.0371 \\
0.0318 & 0.0388 & 0.0352 & 0.0339 & 0.0309 \\
0.0003 & 0.0020 & -0.0019 & -0.0086 & -0.0127 \\
0.0066 & 0.0084 & 0.0077 & 0.0074 & 0.0071 \\
-0.0006 & 0.0000 & 0.0003 & 0.0003 & 0.0001 \\
0.0009 & 0.0008 & 0.0007 & 0.0006 & 0.0005 \\
0.1661 & 0.1562 & 0.1646 & 0.1746 & 0.1759 \\
0.0259 & 0.0314 & 0.0285 & 0.0273 & 0.0262 \\
-0.0008 & -0.0010 & -0.0015 & -0.0021 & -0.0023 \\
0.0010 & 0.0012 & 0.0010 & 0.0010 & 0.0010 \\
0.0021 & 0.0055 & 0.0080 & 0.0130 & 0.0160 \\
0.0079 & 0.0104 & 0.0101 & 0.0104 & 0.0100
\end{tabular}

\begin{tabular}{ccccc}
$\mathrm{k}=1$ & 2 & 3 & 4 & 5 \\
\hline \multicolumn{2}{l}{ Weighting matrix IV } & & & \\
-0.1533 & -0.1510 & -0.1492 & -0.1304 & -0.1143 \\
0.0385 & 0.0465 & 0.0486 & 0.0473 & 0.0455 \\
0.0119 & 0.0189 & 0.0229 & 0.0187 & 0.0143 \\
0.0085 & 0.0102 & 0.0108 & 0.0105 & 0.0100 \\
-0.0003 & 0.0004 & 0.0008 & 0.0009 & 0.0006 \\
0.0007 & 0.0007 & 0.0006 & 0.0004 & 0.0004 \\
0.1000 & 0.0689 & 0.0313 & 0.0334 & 0.0231 \\
0.0340 & 0.0404 & 0.0405 & 0.0389 & 0.0361 \\
0.0005 & 0.0007 & 0.0014 & 0.0012 & 0.0013 \\
0.0011 & 0.0014 & 0.0014 & 0.0014 & 0.0013 \\
0.0098 & 0.0109 & 0.0118 & 0.0145 & 0.0208 \\
0.0095 & 0.0116 & 0.0117 & 0.0111 & 0.0109
\end{tabular}

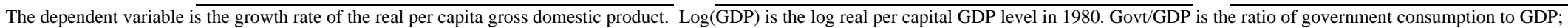

Trade/GDP is the sum of exports and imports of goods and services measured as a share of GDP; Inflation as measured by the annual growth rate of the GDP implicit deflator; Enrollment is the

secondary school enrollment ratio; PrivCredit/GDP is private credit divided by GDP. Weighing matrix II refers to a correction for cross-sectional heteroskedasticity and SUR effects; weighting matrix III refers

to a correction for cross-sectional heteroskedasticity; and weighting matrix IV refers to a simple pooled OLS. All standard errors are robust, accounting for the overlapping nature of the data. 
Table 7

Macroeconomic, banking, and stock market control variables and economic growth

30 Countries, 1981-1997

Horizon in years

\begin{tabular}{ccccr}
$\mathrm{k}=1$ & 2 & 3 & 4 & 5 \\
\hline Weighting matrix II & & & \\
-0.1532 & -0.1577 & -0.1593 & -0.1529 & -0.1474 \\
0.0329 & 0.0326 & 0.0324 & 0.0317 & 0.0303 \\
0.0241 & 0.0311 & 0.0334 & 0.0321 & 0.0306 \\
0.0076 & 0.0078 & 0.0080 & 0.0079 & 0.0075 \\
-0.0006 & 0.0001 & 0.0004 & 0.0005 & 0.0004 \\
0.0009 & 0.0008 & 0.0007 & 0.0006 & 0.0006 \\
0.0638 & 0.0439 & 0.0292 & 0.0267 & 0.0196 \\
0.0310 & 0.0309 & 0.0307 & 0.0298 & 0.0287 \\
-0.0016 & -0.0020 & -0.0022 & -0.0023 & -0.0023 \\
0.0010 & 0.0010 & 0.0010 & 0.0010 & 0.0010 \\
0.0029 & 0.0071 & 0.0117 & 0.0162 & 0.0220 \\
0.0100 & 0.0100 & 0.0099 & 0.0098 & 0.0094 \\
-0.0077 & -0.0133 & -0.0176 & -0.0204 & -0.0291 \\
0.0056 & 0.0056 & 0.0053 & 0.0050 & 0.0051 \\
0.0042 & 0.0049 & 0.0054 & 0.0054 & 0.0055 \\
0.0010 & 0.0010 & 0.0011 & 0.0011 & 0.0010 \\
0.0223 & 0.0184 & 0.0177 & 0.0143 & 0.0115 \\
0.0055 & 0.0053 & 0.0055 & 0.0052 & 0.0053
\end{tabular}

\begin{tabular}{ccccr}
$\mathrm{k}=1$ & 2 & 3 & 4 & 5 \\
\hline Weighting matrix III & & & \\
-0.1583 & -0.1652 & -0.1638 & -0.1590 & -0.1492 \\
0.0334 & 0.0335 & 0.0333 & 0.0324 & 0.0309 \\
0.0254 & 0.0337 & 0.0357 & 0.0342 & 0.0311 \\
0.0077 & 0.0080 & 0.0081 & 0.0081 & 0.0076 \\
-0.0006 & 0.0001 & 0.0004 & 0.0005 & 0.0003 \\
0.0009 & 0.0008 & 0.0007 & 0.0006 & 0.0006 \\
0.0511 & 0.0250 & 0.0118 & 0.0126 & 0.0111 \\
0.0307 & 0.0308 & 0.0308 & 0.0300 & 0.0288 \\
-0.0015 & -0.0019 & -0.0022 & -0.0023 & -0.0023 \\
0.0010 & 0.0011 & 0.0011 & 0.0010 & 0.0010 \\
0.0042 & 0.0098 & 0.0144 & 0.0186 & 0.0247 \\
0.0101 & 0.0102 & 0.0102 & 0.0100 & 0.0096 \\
-0.0077 & -0.0134 & -0.0174 & -0.0201 & -0.0294 \\
0.0056 & 0.0058 & 0.0055 & 0.0051 & 0.0052 \\
0.0045 & 0.0054 & 0.0058 & 0.0058 & 0.0058 \\
0.0010 & 0.0010 & 0.0011 & 0.0011 & 0.0011 \\
0.0221 & 0.0186 & 0.0180 & 0.0150 & 0.0119 \\
0.0055 & 0.0054 & 0.0056 & 0.0054 & 0.0054
\end{tabular}

\begin{tabular}{ccccc}
$\mathrm{k}=1$ & 2 & 3 & 4 & 5 \\
\hline Weighting matrix IV & & & \\
& & & & \\
-0.1583 & -0.1652 & -0.1638 & -0.1590 & -0.1492 \\
0.0334 & 0.0335 & 0.0333 & 0.0324 & 0.0309 \\
0.0254 & 0.0337 & 0.0357 & 0.0342 & 0.0311 \\
0.0077 & 0.0080 & 0.0081 & 0.0081 & 0.0076 \\
-0.0006 & 0.0001 & 0.0004 & 0.0005 & 0.0003 \\
0.0009 & 0.0008 & 0.0007 & 0.0006 & 0.0006 \\
0.0511 & 0.0250 & 0.0118 & 0.0126 & 0.0111 \\
0.0307 & 0.0308 & 0.0308 & 0.0300 & 0.0288 \\
-0.0015 & -0.0019 & -0.0022 & -0.0023 & -0.0023 \\
0.0010 & 0.0011 & 0.0011 & 0.0010 & 0.0010 \\
0.0042 & 0.0098 & 0.0144 & 0.0186 & 0.0247 \\
0.0101 & 0.0102 & 0.0102 & 0.0100 & 0.0096 \\
-0.0077 & -0.0134 & -0.0174 & -0.0201 & -0.0294 \\
0.0056 & 0.0058 & 0.0055 & 0.0051 & 0.0052 \\
0.0045 & 0.0054 & 0.0058 & 0.0058 & 0.0058 \\
0.0010 & 0.0010 & 0.0011 & 0.0011 & 0.0011 \\
0.0221 & 0.0186 & 0.0180 & 0.0150 & 0.0119 \\
0.0055 & 0.0054 & 0.0056 & 0.0054 & 0.0054
\end{tabular}

The dependent variable is the growth rate of the real per capita gross domestic product. $\log (\mathrm{GDP})$ is the log real per capital GDP level in 1980. Govt/GDP is the ratio of government consumption to GDP; Trade/GDP is the sum of exports and imports of goods and services measured as a share of GDP; Inflation as measured by the annual growth rate of the GDP implicit deflator; Enrollment is the

secondary school enrollment ratio; PrivCredit/GDP is private credit divided by GDP; $\log$ (\# of stocks) is the log of the number of domestic companies; Turnover is the ratio of equity market value traded

to the MCAP. Weighing matrix II refers to a correction for cross-sectional heteroskedasticity and SUR effects; weighting matrix III refers to a correction for cross-sectional heteroskedasticity; and weighting

matrix IV refers to a simple pooled OLS. All standard errors are robust, accounting for the overlapping nature of the data. 
Table 8

Liberalization and growth controling for macroeconomic, banking and stock market development control variables

30 Countries, 1981-1997

Horizon in years

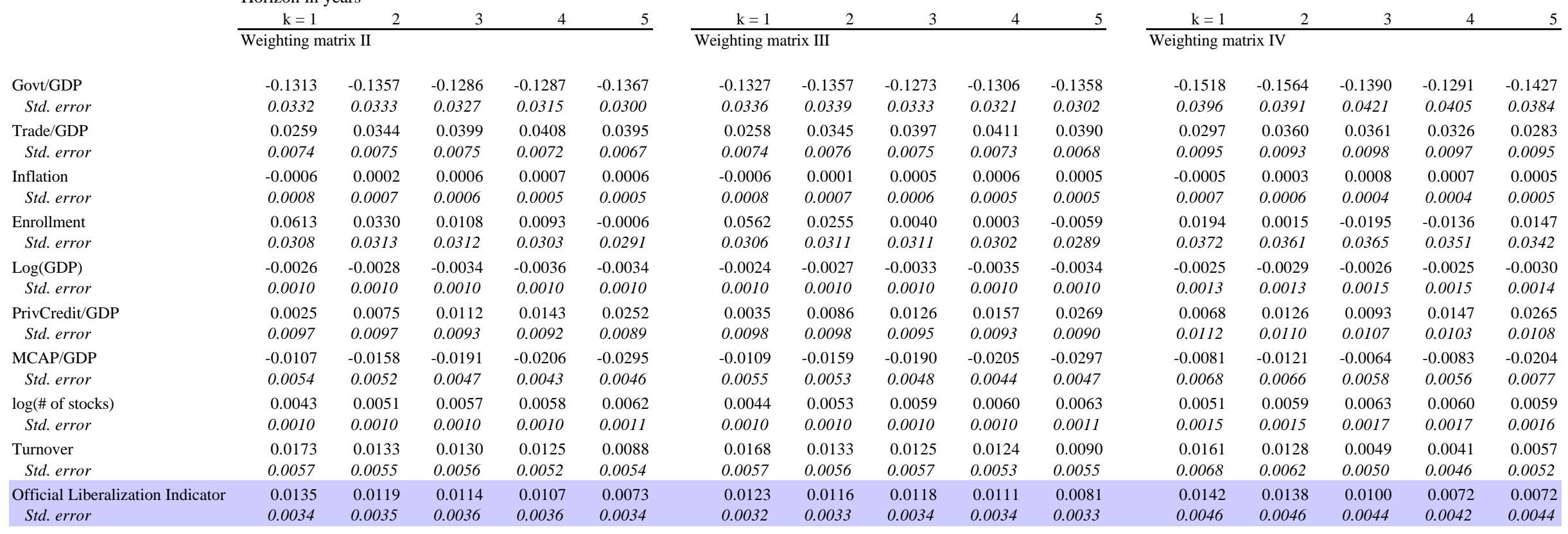

The dependent variable is the growth rate of the real per capita gross domestic product. Log(GDP) is the log real per capital GDP level in 1980. Govt/GDP is the ratio of government consumption to GDP;

Trade/GDP is the sum of exports and imports of goods and services measured as a share of GDP; Inflation as measured by the annual growth rate of the GDP implicit deflator; Enrollment is the

secondary school enrollment ratio; PrivCredit/GDP is private credit divided by GDP; $\log$ (\# of stocks) is the log of the number of domestic companies; Turnover is the ratio of equity market value traded

to the MCAP and the official liberalization variable takes a value of one when the equity market is liberalized, and zero otherwise. Weighing matrix II refers to a correction for cross-sectional heteroskedasticity and

SUR effects; weighting matrix III refers to a correction for cross-sectional heteroskedasticity; and weighting matrix IV refers to a simple pooled OLS. All standard errors are robust, accounting for the overlapping nature

of the data. 
Table 9

The Robustness of the Growth-Liberalization Relation

30 Countries, 1981-1997

A. Does one region drive the impact of liberalizations on economic growth?

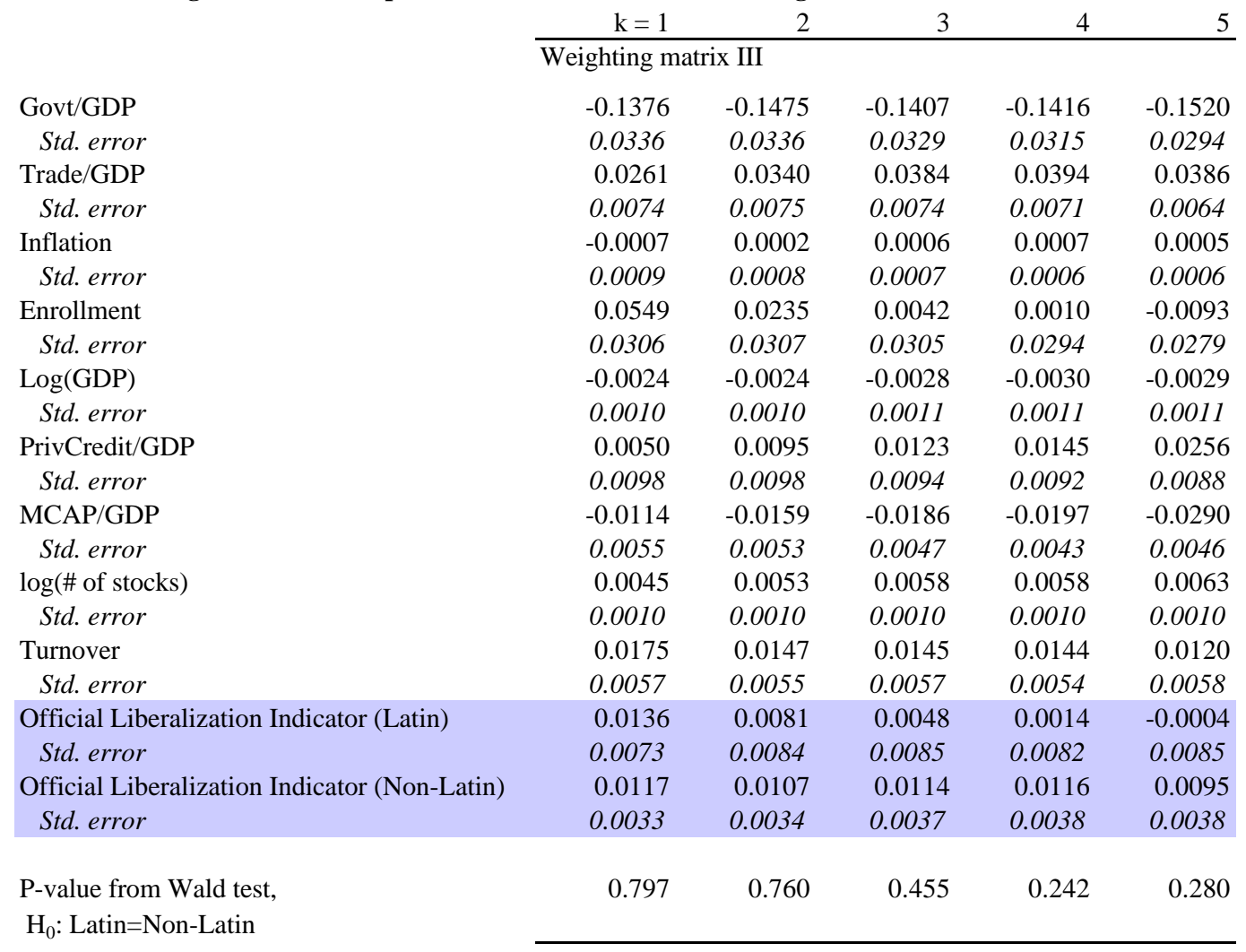

B. Does the size of the government sector explain the impact of liberalizations on economic growth?

\begin{tabular}{|c|c|c|c|c|c|}
\hline & $\mathrm{k}=1$ & 2 & 3 & 4 & 5 \\
\hline & Weighting $\mathrm{m}$ & X III & & & \\
\hline Govt/GDP & -0.1309 & -0.1276 & -0.1169 & -0.1230 & -0.1304 \\
\hline Std. error & 0.0336 & 0.0341 & 0.0337 & 0.0326 & 0.0309 \\
\hline Trade/GDP & 0.0258 & 0.0346 & 0.0403 & 0.0419 & 0.0387 \\
\hline Std. error & 0.0075 & 0.0077 & 0.0078 & 0.0075 & 0.0071 \\
\hline Inflation & -0.0006 & 0.0002 & 0.0006 & 0.0006 & 0.0005 \\
\hline Std. error & 0.0008 & 0.0007 & 0.0006 & 0.0005 & 0.0004 \\
\hline Enrollment & 0.0566 & 0.0240 & -0.0026 & -0.0071 & -0.0106 \\
\hline Std. error & 0.0309 & 0.0319 & 0.0322 & 0.0313 & 0.0300 \\
\hline $\log (\mathrm{GDP})$ & -0.0025 & -0.0029 & -0.0035 & -0.0035 & -0.0032 \\
\hline Std. error & 0.0010 & 0.0010 & 0.0010 & 0.0010 & 0.0010 \\
\hline PrivCredit/GDP & 0.0034 & 0.0083 & 0.0133 & 0.0169 & 0.0269 \\
\hline Std. error & 0.0098 & 0.0100 & 0.0098 & 0.0096 & 0.0092 \\
\hline MCAP/GDP & -0.0109 & -0.0158 & -0.0194 & -0.0215 & -0.0303 \\
\hline Std. error & 0.0056 & 0.0054 & 0.0049 & 0.0045 & 0.0047 \\
\hline $\log (\#$ of stocks $)$ & 0.0044 & 0.0053 & 0.0060 & 0.0061 & 0.0061 \\
\hline Std. error & 0.0010 & 0.0010 & 0.0010 & 0.0010 & 0.0010 \\
\hline Turnover & 0.0166 & 0.0121 & 0.0108 & 0.0109 & 0.0080 \\
\hline Std. error & 0.0057 & 0.0056 & 0.0057 & 0.0053 & 0.0054 \\
\hline Official Liberalization Indicator (Big Gov.) & 0.0128 & 0.0122 & 0.0119 & 0.0117 & 0.0080 \\
\hline Std. error & 0.0045 & 0.0047 & 0.0047 & 0.0046 & 0.0041 \\
\hline Official Liberalization Indicator (Small Gov.) & 0.0122 & 0.0127 & 0.0144 & 0.0134 & 0.0093 \\
\hline Std. error & 0.0039 & 0.0042 & 0.0045 & 0.0047 & 0.0049 \\
\hline $\begin{array}{l}\text { P-value from Wald test, } \\
\mathrm{H}_{0}: \text { Big Gov.=Small Gov. }\end{array}$ & 0.920 & 0.926 & 0.681 & 0.792 & 0.829 \\
\hline
\end{tabular}


Table 9 (continued)

\section{The Robustness of the Growth-Liberalization Relation}

C. The influence of education on the relation between financial market liberalization and economic growth

\begin{tabular}{|c|c|c|c|c|c|}
\hline & $\mathrm{k}=1$ & 2 & 3 & 4 & 5 \\
\hline & Weighting $\mathrm{m}$ & IX III & & & \\
\hline Govt/GDP & -0.1283 & -0.1322 & -0.1218 & -0.1256 & -0.1338 \\
\hline Std. error & 0.0337 & 0.0336 & 0.0328 & 0.0313 & 0.0294 \\
\hline Trade/GDP & 0.0252 & 0.0341 & 0.0393 & 0.0406 & 0.0389 \\
\hline Std. error & 0.0075 & 0.0075 & 0.0075 & 0.0071 & 0.0065 \\
\hline Inflation & -0.0005 & 0.0002 & 0.0005 & 0.0006 & 0.0004 \\
\hline Std. error & 0.0008 & 0.0007 & 0.0006 & 0.0005 & 0.0005 \\
\hline Enrollment & 0.0502 & 0.0138 & -0.0051 & -0.0093 & -0.0166 \\
\hline Std. error & 0.0307 & 0.0309 & 0.0308 & 0.0296 & 0.0281 \\
\hline $\log (\mathrm{GDP})$ & -0.0023 & -0.0026 & -0.0033 & -0.0034 & -0.0033 \\
\hline Std. error & 0.0010 & 0.0010 & 0.0010 & 0.0010 & 0.0010 \\
\hline PrivCredit/GDP & 0.0037 & 0.0097 & 0.0141 & 0.0174 & 0.0272 \\
\hline Std. error & 0.0098 & 0.0097 & 0.0094 & 0.0091 & 0.0086 \\
\hline MCAP/GDP & -0.0105 & -0.0154 & -0.0190 & -0.0209 & -0.0298 \\
\hline Std. error & 0.0055 & 0.0053 & 0.0047 & 0.0043 & 0.0045 \\
\hline $\log (\#$ of stocks $)$ & 0.0045 & 0.0055 & 0.0060 & 0.0061 & 0.0065 \\
\hline Std. error & 0.0010 & 0.0010 & 0.0010 & 0.0010 & 0.0011 \\
\hline Turnover & 0.0165 & 0.0132 & 0.0122 & 0.0122 & 0.0095 \\
\hline Std. error & 0.0057 & 0.0055 & 0.0056 & 0.0053 & 0.0054 \\
\hline Official Liberalization Indicator (+School) & 0.0140 & 0.0136 & 0.0144 & 0.0147 & 0.0118 \\
\hline Std. error & 0.0035 & 0.0037 & 0.0041 & 0.0042 & 0.0039 \\
\hline Official Liberalization Indicator (-School) & 0.0073 & 0.0033 & 0.0044 & 0.0032 & -0.0015 \\
\hline Std. error & 0.0053 & 0.0054 & 0.0054 & 0.0053 & 0.0054 \\
\hline $\begin{array}{l}\text { P-value from Wald test, } \\
\mathrm{H}_{0}:+ \text { School=-School }\end{array}$ & 0.244 & 0.087 & 0.113 & 0.075 & 0.039 \\
\hline
\end{tabular}

D. Early versus late liberalization of financial markets and economic growth

\begin{tabular}{|c|c|c|c|c|c|}
\hline & $\mathrm{k}=1$ & 2 & 3 & 4 & 5 \\
\hline & Weighting $\mathrm{m}$ & $\mathrm{x}$ III & & & \\
\hline Govt/GDP & -0.1242 & -0.1175 & -0.1056 & -0.1030 & -0.0752 \\
\hline Std. error & 0.0354 & 0.0370 & 0.0381 & 0.0370 & 0.0313 \\
\hline Trade/GDP & 0.0247 & 0.0340 & 0.0384 & 0.0388 & 0.0357 \\
\hline Std. error & 0.0079 & 0.0086 & 0.0092 & 0.0090 & 0.0088 \\
\hline Inflation & -0.0006 & 0.0002 & 0.0007 & 0.0008 & 0.0007 \\
\hline Std. error & 0.0008 & 0.0007 & 0.0005 & 0.0004 & 0.0004 \\
\hline Enrollment & 0.0593 & 0.0276 & 0.0003 & -0.0087 & -0.0004 \\
\hline Std. error & 0.0316 & 0.0330 & 0.0343 & 0.0337 & 0.0318 \\
\hline $\log (\mathrm{GDP})$ & -0.0026 & -0.0031 & -0.0035 & -0.0035 & -0.0036 \\
\hline Std. error & 0.0011 & 0.0011 & 0.0013 & 0.0012 & 0.0012 \\
\hline PrivCredit/GDP & 0.0029 & 0.0085 & 0.0154 & 0.0200 & 0.0190 \\
\hline Std. error & 0.0100 & 0.0105 & 0.0111 & 0.0112 & 0.0103 \\
\hline MCAP/GDP & -0.0102 & -0.0148 & -0.0155 & -0.0152 & -0.0222 \\
\hline Std. error & 0.0058 & 0.0060 & 0.0067 & 0.0069 & 0.0095 \\
\hline $\log (\#$ of stocks) & 0.0044 & 0.0052 & 0.0054 & 0.0050 & 0.0046 \\
\hline Std. error & 0.0011 & 0.0011 & 0.0014 & 0.0015 & 0.0015 \\
\hline Turnover & 0.0137 & 0.0094 & 0.0078 & 0.0072 & 0.0068 \\
\hline Std. error & 0.0064 & 0.0062 & 0.0066 & 0.0063 & 0.0060 \\
\hline Official Liberalization Indicator (Early) & 0.0139 & 0.0136 & 0.0143 & 0.0161 & 0.0149 \\
\hline Std. error & 0.0037 & 0.0041 & 0.0047 & 0.0049 & 0.0050 \\
\hline Official Liberalization Indicator (Late) & 0.0139 & 0.0157 & 0.0181 & 0.0191 & 0.0265 \\
\hline Std. error & 0.0061 & 0.0078 & 0.0134 & 0.0205 & 0.0434 \\
\hline $\begin{array}{l}\text { P-value from Wald test, } \\
\mathrm{H}_{0}: \text { Early=Late }\end{array}$ & 1.000 & 0.803 & 0.785 & 0.885 & 0.790 \\
\hline
\end{tabular}


Table 9 (continued)

\section{The Robustness of the Growth-Liberalization Relation}

\begin{tabular}{|c|c|c|c|c|c|}
\hline \multicolumn{6}{|c|}{ E. Liberalization and growth excluding the financially-oriented control variables } \\
\hline & $\mathrm{k}=1$ & 2 & 3 & 4 & 5 \\
\hline & \multicolumn{5}{|c|}{ Weighting matrix III } \\
\hline Govt/GDP & -0.0507 & -0.0397 & -0.0280 & -0.0272 & -0.0403 \\
\hline Std. error & 0.0316 & 0.0324 & 0.0335 & 0.0327 & 0.0303 \\
\hline Trade/GDP & 0.0010 & -0.0019 & -0.0043 & -0.0076 & -0.0060 \\
\hline Std. error & 0.0063 & 0.0066 & 0.0068 & 0.0068 & 0.0070 \\
\hline Enrollment & -0.0006 & -0.0001 & 0.0002 & 0.0003 & 0.0002 \\
\hline Std. error & 0.0008 & 0.0007 & 0.0006 & 0.0005 & 0.0005 \\
\hline $\log (\mathrm{GDP})$ & 0.1702 & 0.1821 & 0.1852 & 0.1834 & 0.1671 \\
\hline Std. error & 0.0250 & 0.0254 & 0.0265 & 0.0267 & 0.0272 \\
\hline Inflation & -0.0018 & -0.0024 & -0.0028 & -0.0029 & -0.0025 \\
\hline Std. error & 0.0009 & 0.0010 & 0.0010 & 0.0010 & 0.0010 \\
\hline PrivCredit/GDP & -0.0082 & -0.0042 & -0.0001 & 0.0069 & 0.0112 \\
\hline Std. error & 0.0077 & 0.0086 & 0.0094 & 0.0097 & 0.0093 \\
\hline Official Liberalization Indicator & 0.0159 & 0.0157 & 0.0149 & 0.0127 & 0.0095 \\
\hline Std. error & 0.0030 & 0.0032 & 0.0034 & 0.0035 & 0.0036 \\
\hline
\end{tabular}

The dependent variable is the growth rate of the real per capita gross domestic product. $\log (\mathrm{GDP})$ is the log real per capital GDP level in 1980. Govt/GDP is the ratio of government consumption to GDP; Trade/GDP is the sum of exports and imports of goods and services measured as a share of GDP; Inflation as measured by the annual growth rate of the GDP implicit deflator; Enrollment is the secondary school enrollment ratio; PrivCredit/GDP is private credit divided by GDP; $\log$ (\# of stocks) is the log of the number of domestic companies; Turnover is the ratio of equity market value traded to the MCAP and the official liberalization variable takes a value of one when the equity market is liberalized, and zero otherwise. Latin refers to an indicator that takes the value of one if the country is in Latin America. BigGov takes the value of one for the country has a larger than median gov/GDP ratio. +School takes the value of one for the country has a larger than median secondary school enrollment ratio. Early takes the value of one for countries that underwent a financial liberalization before 1991, the median liberalization date. Weighing matrix II refers to a correction for cross-sectional heteroskedasticity and SUR effects; weighting matrix III refers to a correction for cross-sectional heteroskedasticity; and weighting matrix IV refers to a simple pooled OLS. All standard errors are robust, accounting for the overlapping nature of the data. 


\section{Appendix Table A}

\section{Monte Carlo Structure}

Cross Sectionally Restricted VAR used in Monte Carlo for constructing control variables.

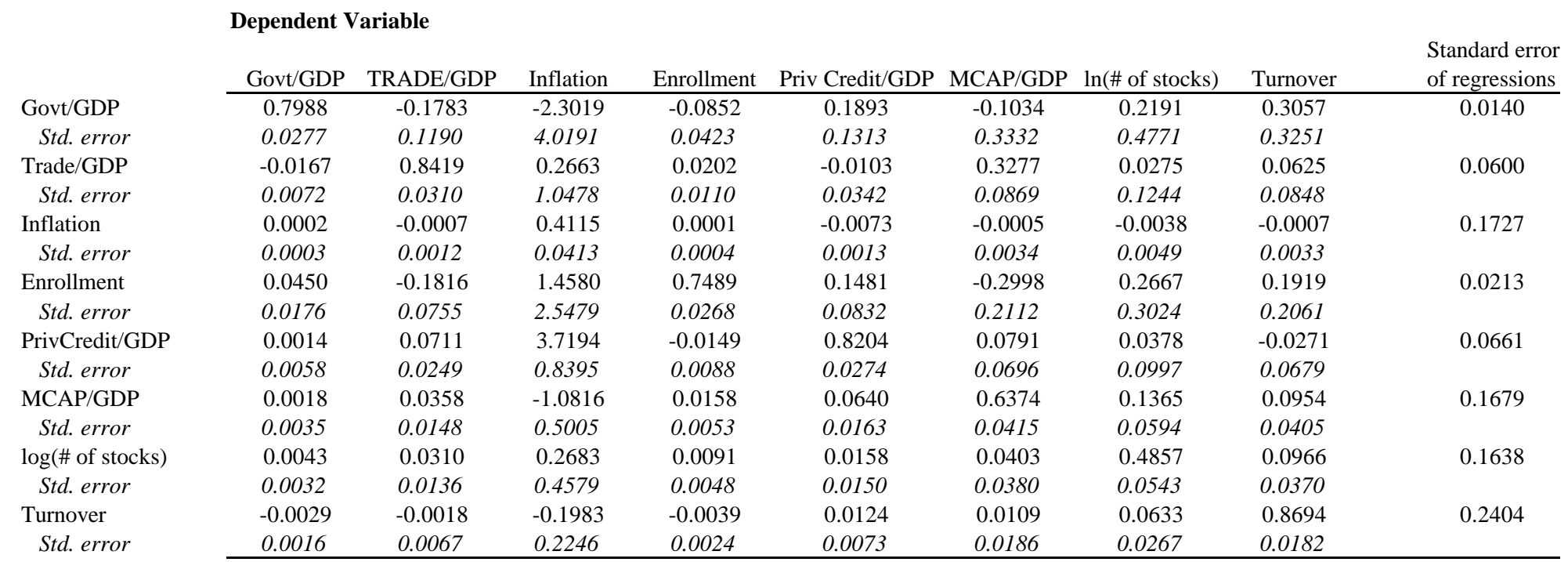

To generate control (right-hand side) variables for our Monte Carlo, we estimate a VAR on Gov/GDP, Trade/GDP, Inflation, Enrollment, PrivCred/GDP,

$\log$ (\# of stocks), and turnover, restricting the coefficients (reported) to be identical across countries but allowing for country specific intercepts (not reported).

\section{Cross Sectionally Restricted MA coefficient used in Monte Carlo for constructing residuals}

\begin{tabular}{lcccc} 
& $\mathrm{MA}(1)$ & $\mathrm{MA}(2)$ & $\mathrm{MA}(3)$ & $\mathrm{MA}(4)$ \\
\cline { 2 - 5 } $\mathrm{k}=2$ & 0.778 & & & \\
Std. error & 0.043 & & & \\
$\mathrm{k}=3$ & 0.786 & 0.494 & & \\
Std. error & 0.166 & 0.142 & & \\
$\mathrm{k}=4$ & 0.695 & 0.498 & 0.337 & \\
Std. error & 0.186 & 0.155 & 0.156 & 0.008 \\
$\mathrm{k}=5$ & 0.900 & 0.685 & 0.317 & 0.294 \\
Std. error & 0.289 & 0.301 & 0.339 & \\
To generate the moving average structure of the dependent (left-hand side) variable in our Monte
\end{tabular}

To generate the moving average structure of the dependent (left-hand side) variable in or

Carlo, we estimate an MA(k-1) $(\mathrm{k}=2, \ldots, 5)$ for the residuals from the estimations performed in

Table 7, restricting the MA coefficients to be identical across countries. The estimation is

performed using QMLE, assuming uncorrelated errors across countries and normal shocks

in the likelihood. 
Appendix Table B

Monte Carlo Analysis

MONTE CARLO: 1000 Replications

Coefficient on Liberalization Indicator Horizon in years

Mean

Median

Std. Dev.

Skewness

Kurtosis

$2.50 \%$
$97.50 \%$

Jarque-Bera

Probability

\section{MONTE CARLO: 1000 Replication}

Weighting Matrix III

Coefficient on Liberalization Indicato

Mean

Media

Std. Dev.

Skewness

Kurtosis

$2.50 \%$

$97.50 \%$

Jarque-Bera

Probability

\begin{tabular}{rrrrr}
$\mathrm{k}=1$ & \multicolumn{1}{c}{2} & \multicolumn{1}{c}{3} & \multicolumn{1}{c}{4} & \multicolumn{1}{c}{5} \\
\hline 0.0000 & -0.0002 & 0.0000 & 0.0003 & 0.0002 \\
0.0001 & -0.0002 & 0.0001 & 0.0002 & 0.0003 \\
0.0035 & 0.0047 & 0.0050 & 0.0053 & 0.0054 \\
0.0312 & 0.0099 & 0.0539 & 0.0363 & -0.1494 \\
3.0587 & 3.0957 & 3.1887 & 2.8061 & 3.0049 \\
-0.0069 & -0.0092 & -0.0099 & -0.0101 & -0.0112 \\
0.0065 & 0.0092 & 0.0103 & 0.0105 & 0.0105 \\
& & & & \\
0.3056 & 0.3976 & 1.9689 & 1.7873 & 3.7216 \\
0.8583 & 0.8197 & 0.3737 & 0.4092 & 0.1555 \\
\hline
\end{tabular}

T-statistic on Null Hypothesis Horizon in years

\begin{tabular}{lrrrrrr} 
& \multicolumn{1}{c}{$\mathrm{k}=1$} & \multicolumn{1}{c}{2} & \multicolumn{1}{c}{3} & \multicolumn{1}{c}{5} & $\mathrm{~N}(0,1)$ \\
\cline { 2 - 7 } Mean & -0.0050 & -0.0426 & -0.0018 & 0.0607 & 0.0362 & 0.000 \\
Median & 0.0373 & -0.0486 & 0.0142 & 0.0355 & 0.0605 & 0.000 \\
Std. Dev. & 1.0169 & 1.1727 & 1.1301 & 1.1443 & 1.1404 & 1.000 \\
Skewness & 0.0355 & -0.0248 & 0.0015 & 0.0768 & -0.1244 & 0.000 \\
Kurtosis & 3.0170 & 3.2067 & 3.1956 & 2.7769 & 3.0323 & 3.000 \\
$2.50 \%$ & -1.9710 & -2.3223 & -2.3009 & -2.1631 & -2.2771 & -1.960 \\
$97.50 \%$ & 1.9040 & 2.2696 & 2.2023 & 2.2280 & 2.3086 & 1.960 \\
& & & & & & \\
Jarque-Bera & 0.2220 & 1.8831 & 1.5949 & 3.0569 & 2.6235 & \\
Probability & 0.8950 & 0.3900 & 0.4505 & 0.2169 & 0.2694 & \\
& & & & & & \\
\end{tabular}

T-statistic on Null Hypothesis

Median

Std. Dev.

Skewness

$2.50 \%$

$97.50 \%$

Jarque-Bera

Probability

\begin{tabular}{rrrrrr}
$\mathrm{k}=1$ & \multicolumn{1}{c}{2} & \multicolumn{1}{c}{3} & \multicolumn{1}{c}{4} & \multicolumn{1}{c}{5} & $\mathrm{~N}(0,1)$ \\
\hline 0.0339 & -0.0661 & -0.0219 & 0.0953 & 0.0340 & 0.000 \\
0.0660 & -0.0470 & -0.0372 & 0.0531 & 0.0151 & 0.000 \\
1.0888 & 1.6476 & 1.6387 & 1.7479 & 1.7790 & 1.000 \\
-0.0294 & -0.0790 & -0.0266 & -0.0166 & 0.0675 & 0.000 \\
3.0403 & 2.9542 & 3.0376 & 3.0797 & 2.8988 & 3.000 \\
-2.0612 & -3.2345 & -3.2844 & -3.2361 & -3.2532 & -1.960 \\
2.1193 & 3.1524 & 3.2914 & 3.1836 & 3.2184 & 1.960 \\
& & & & & \\
0.2122 & 1.1282 & 0.1771 & 0.3107 & 1.1869 & \\
0.8993 & 0.5689 & 0.9153 & 0.8561 & 0.5524 & \\
& & & & & \\
\hline
\end{tabular}

MONTE CARLO: 1000 Replication

Weighting Matrix II

Coefficient on Liberalization Indicator

Mean

Median

Std. Dev.

Skewness

$2.50 \%$

$97.50 \%$

Jarque-Bera

Probability

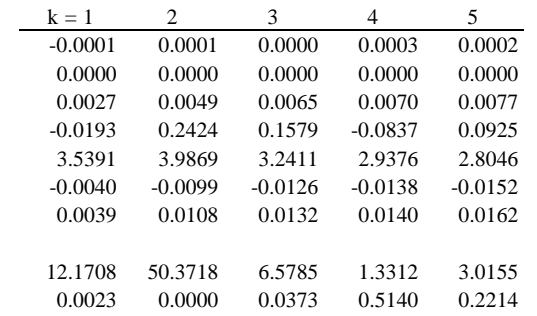

T-statistic on Null Hypothesis

Mean

Median

Std. Dev.
Skewness

Kurtosis

$2.50 \%$

$97.50 \%$

Jarque-Bera
Probability

\begin{tabular}{rrrrrr}
$\mathrm{k}=1$ & \multicolumn{1}{c}{2} & \multicolumn{1}{c}{3} & \multicolumn{1}{c}{4} & \multicolumn{1}{c}{5} & $\mathrm{~N}(0,1)$ \\
\hline-0.0002 & 0.0250 & -0.0168 & 0.0891 & 0.1017 & 0.0000 \\
0.0000 & 0.0000 & -0.0188 & 0.0817 & 0.0688 & 0.0000 \\
1.2006 & 1.6480 & 1.6548 & 1.8059 & 1.8076 & 1.0000 \\
-0.1564 & -0.0301 & 0.0712 & -0.0563 & 0.1424 & 0.0000 \\
3.7899 & 3.5564 & 3.3945 & 3.1604 & 3.8650 & 3.0000 \\
-2.4329 & -3.2895 & -3.2882 & -3.4898 & -3.3569 & -1.9600 \\
2.3986 & 3.2754 & 3.2947 & 3.4111 & 3.5064 & 1.9600 \\
& & & & & \\
30.0764 & 13.0491 & 7.3291 & 1.5998 & 34.5577 & \\
0.0000 & 0.0015 & 0.0256 & 0.4494 & 0.0000 &
\end{tabular}

We report summary statistics for both the estimated coefficient on the official liberalization indicator and the corresponding t-statistic from our Monte Carlo analysis for weighting matrices II, III, and IV.

We also report $2.5 \%$ and $97.5 \%$ percentiles for comparison with the critical values we obtain in our regression specifications. 